Türkiye Jeoloji Bülteni
Geological Bulletin of Turkey
$61(2018) 241-268$
doi: $10.25288 /$ tjb.458432

\title{
Çanakkale Yöresi (KB Türkiye) Erenköy ve Güzelyalı Fosil Heyelanlarının Jeolojik ve Jeomorfolojik Analizi
}

\author{
Geological and Geomorphological Analysis of the Ancient Erenköy and \\ Güzelyalı Landslides in the Çanakkale District, NW Turkey
}

\author{
Doğan Perinçek ${ }^{* 1}$ \\ ${ }^{1}$ Emekli, Çanakkale Onsekiz Mart Üniversitesi, Mühendislik Fakültesi, Jeoloji Mühendisliği Bölümü, 17020 \\ Çanakkale
}

Geliş/Received : 30.01.2018 • Düzeltilmiş Metin Geliş/Revised Manuscript Received : 15.07.2018 • Kabul/Accepted : 16.07.2018 • Bask1/Printed : 12.09 .2018 Araştırma Makalesi/Research Article Türkije Jeol. Bül. / Geol. Bull. Turkey

Öz: Bu çalışmada Çanakkale'ye bağlı Güzelyalı Köyü dolayındaki eski heyelan döküntüsü incelenmiş ve ayrıca Erenköy kuzeydoğusundaki tarihsel büyük heyelanların izleri ortaya çıkarılmıştır. Bu kapsamda, söz konusu heyelanların oluşum ve gelişim nedenlerini, jeolojik ve jeomorfolojik yöntemlerle analiz ederek, heyelanı oluşturan hazırlayıcı ve tetikleyici etmenleri belirlemek amaçlanmıştır. Bu makalede 1875 Erenköy-Çanakkale Depremlerinin tetiklediği Erenköy yakınındaki heyelanlarla ilgili veriler sunulmaktadır. Erenköy-Güzelyalı dolayındaki eski heyelanlar kompleksinin yayılım alanı Çanakkale dolayındaki en büyük heyelan alanlarından bir tanesidir. Tarihsel heyelan alanının büyüklüğü yaklaşık $3.75 \mathrm{~km}^{2}$ dir. Erenköy yakınındaki bu tarihsel büyük heyelanlar, iki karakteristik yeryüzü özelikleri ile arazide fark edilmektedir. Bunlar yamacın dibinde düzensiz biçimde dökülmüş halde yüzeyleyen kayaçların karışık bir görüntü sunması ve kaymanın geldiği tepelerde konkav ya da keskin-düz görünüşlü kesik topografyadır. 1875 Erenköy Depreminden sonraki yıllarda alanda süregelen erozyon, heyelanın yüzeydeki bazı topoğrafik verilerini kısmen silmiştir. Güzelyalı köyü yakınındaki eski heyelan döküntüsünün ise çok sayıda tekrarlayan akma (krip) tipi heyelanlarla oluştuğu düşünülmektedir. Birbiri arasında belki de yüzyıllar olan çok sayıda tekrarlanmış olabilecek bu heyelanların bazılarının bölge ve yakın dolayında tarihsel dönemlerde meydana gelmiş depremlerle yer yer tetiklenmiş olması olasıdır. Güzelyalı heyelan döküntüsü yakın geçmişte krip tipi heyelanlar olarak tekrar hareket etmiştir. Eski heyelan döküntüsü Güzelyalı yerleşim alanının kuzeydoğusundaki konutlar için tehlikeli olmaktadır. Güzelyalı Köyü’ndeki eski heyelan döküntüsü ve ilgili heyelanların ilk oluşum yaşı, Erenköy Heyelanından öncedir.

Anahtar Kelimeler: Çanakkale, Erenköy, Güzelyall, heyelan, krip, rotasyonal heyelan.

Abstract: The study was able to describe the ancient landslide debris around Güzelyall Village. Also, the remains of horrendous ancient landslides have been discovered in northeast of Erenköy Village in Çanakkale. In this frame, aim of the study is to determine the preparatory and triggering factors that form the landslides by analyzing the occurrence and development mechanisms of these landslides with the geological and geomorphologic methods. The evidence for the ancient landslide triggered by 1875 Erenköy-Çanakkale Earthquake presented in this paper, which is located near Erenköy. Ancient landslide complex around Erenköy-Güzelyalı area has the distinction of having one of the largest, landslides in Canakkale. The total area of the ancient landslides is approximately 3.75 square kilometers in size. Historical landslides near Erenköy have been noticed by land features bearing two hallmark characteristics. These are: a jumbled assortment of rocks at the base of a slope, and a cuplike or sharp-straight topography cut out of the hills where the slide might have come from. Post 1875 erosion activity have partially erased much of the evidence of landslide. It was assumed that landslide deposits near Güzelyalı Village were produced by multiple landslide events. Probably some of the slides, originated by earthquakes consisting of many events, likely several

* Yazışma / Correspondence: perincek@yahoo.com

(C) 2018 JMO Her hakkı saklıdır/All rights reserved http://tjb.jmo.org.tr http://dergipark.gov.tr/tjb 
hundred years between them. Mentioned landslide debris was recently moved again as creep-type landslides. Ancient landslide debris offers danger signs for northeastern Güzelyalı housing developments. Ancient Güzelyalı s landslide debris and related landslide is older than Erenköy's landslide.

Keywords: Çanakkale, Erenköy, Güzelyal, landslide, creep, rotational slide.

\section{GíRiș}

$\mathrm{Bu}$ çalışma Çanakkale'nin güneyinde merkeze bağlı Erenköy ve Güzelyalı köyleri ve yakın dolayında gelişmiş olan heyelanlar üzerinde gerçekleştirilmiştir (Şekil 1). Heyelanların oluşumunun başlıca iki nedeni vardır; bunlardan birincisi doğal süreçlere bağlı doğa olayları ikincisi ise insan hatalarından kaynaklanan topoğrafik yapıyı bozan yanlış arazi kullanımıdır. Birbirini de tetikleyen bu iki neden bir araya gelince oluşabilecek heyelanların hem can kaybı hem de ekonomik açıdan korkunç boyutta zararlara yol açtığ 1 görülür. Heyelana neden olan doğal olaylar sırasıyla; 1) su-yağmur, 2) deprem ve 3) volkanik aktivitedir. Bazen bunlardan ikisinin bir arada olması heyelanın boyutunu ve etkisini artırır. Yamaç eğiminin derecesi, morfoloji, toprak tipi, bölgenin jeolojisi, kaya türleri doğal olayların etkisini de kontrol eder (Sarker ve Rashid, 2013). Başlıca insan hataları ise yerleşim alanındaki plansız ve düzensiz bina sayısı, yanlış arazi kullanımı ve nüfus arttıkça insanların doğal topoğrafik dengeyi bozmasıdır. İnsanların doğal drenaj düzenini bozması, yamaç eğimine müdahale ederek artırması, bitki örtüsünün azaltılması / ormanın yok edilmesi, yamacın topuk kısmından yük alınması, yamacın üst kısmına ilave yük bindirilmesi zeminin taşıma gücünü azaltır ve heyelanları tetikler. Ayrıca aşırı bahçe sulaması ve yeraltı su şebekesi borularından zemine sızan ek su ilavesi de önemli insan katkısı hatalardan olup heyelana neden olur (Highland ve Bobrowsky 2008). Yol, bina ve benzeri yapılaşma sırasında jeolog ve mühendislerin yamaç duraylılı̆g başta olmak üzere bölgenin jeolojisini, jeomorfolojisini dikkate alarak proje hazırlamaları halinde, hesaba katılmayan sürpriz heyelanlarla karşılaşılaşılmasını önleyecektir. Çanakkale
İzmir karayolunun Erenköy yakınında 2013-2014 yıllarında oluşan heyelanların yol güzergahının jeolojik ve yamaç duraylılığ 1 vb. özellikleri dikkate alınmadan yapılmış ve genişletilmiş olması dolayısıyla insan hatasına bağlı nedenler sonucunda oluştuğu anlaşılmaktadır.

Depremlerin yanı sıra heyelanlar da yerleşim yerlerini, yolları ve hatta uygarlıkları bile yok edebilir. Çanakkale dolayında geçen y1llarda olan heyelanlar nedeniyle köylerin ve yolların tahrip olduğu yapılan çalışmalar ve yayınlarla kayıtlara geçmiştir (Yiğitbaş vd., 2005; Baba vd., 2005; Kürçer vd., 2005; Türkeş vd., 2006; Tunusluoğlu vd., 2009; Erginal vd., 2009; Bekler vd., 2011; Türkeş vd., 2011; Tatar vd., 2011; Ekinci vd., 2013).

$\mathrm{Bu}$ çalışmada 1875 yılında Erenköy kuzeydoğusunda gözlenen tarihsel heyelan ve Güzelyalı dolayında saptanan fosil Güzelyalı heyelan döküntüsü (GHD) ile ilgili veriler aktarılacaktır. Calvi, (1941), AFAD (2010) ve Soysal vd. (1981) tarafindan rapor edilen 1875 Erenköy-Çanakkale Depremi ve ardından oluşan heyelanla ilgili kısıtlı ilk bilgiler bu çalışmanın ilk adımının atılmasını sağlamıştır. Bu verilerden sonra Erenköy çevresindeki alan taranmış ve 1875 Depremi'nin ardından olan heyelanların yeri saptanmıştır. Söz konusu heyelan Erenköy Heyelanı (EH) olarak adlandırılmıştır. Çanakkale İzmir karayolu çalışması sırasında Güzelyalı dolayında açılan yol yarmalarında bu çalışma sırasında yapılan gözlemler ise fosil heyelan döküntüsünün iç yapısının tanınmasında önemli katkısı olmuştur. Yol yapımından önce Güzelyalı dolayında gözlenen kireçtaşı bloklarının varlığı da sorgulanmış ve yol yarmasında izlenen verilerle birleştirilerek eski (fosil) heyelan döküntüsünün 
tanınması sağlanmıştır. Güzelyalı çevresindeki bazı mostralarda heyelan döküntüsünde izlenen bazı çizgisellikler fay olarak da yorumlanabilecek bir görüntüdedir ve yanılgıya neden olmaktadır. Bölgedeki detaylı çalışmalar sonucunda bu yanılgı ortadan kaldırılmıştır.

$\mathrm{Bu}$ eski heyelan arazi çalışması sırasında amaca yönelik olarak GoogleEarth görüntüleri arazi çalışmasıyla birlikte eşzamanlı olarak kullanılmıştır. Erenköy Heyelanının (EH) yaşı heyelanı tetikleyen 1875 Erenköy-Çanakkale Depremi nedeniyle bilinmektedir (Calvi, 1941; Soysal vd., 1981; AFAD, 2010). Güzelyalı heyelan döküntüsünün (GHD) yaşı ise bilinmemektedir. Fakat Erenköy Heyelanından (EH) göreceli olarak daha yaşlı ve birden fazla heyelanla ilgili olduğu kesindir. Bulunduğu alanın jeomorfolojik yapısı, Güzelyalı heyelan döküntüsü malzemesinin önemli ölçüde aşındırılıp taşınması, izlerinin silinmesi, bu döküntü malzemesinin taşınarak Güzelyalı deltasının gelişiminde kaynak alan olarak önemli katkısının olması, heyelan döküntüsü iç yapısının aşırı karmaşık olması, döküntü içindeki kireçtaşı bloklarının varlığ1, blokların döküntü altındaki formasyon (Tga) ile ilgisinin olmamas1, heyelan malzemesinin bulunduğu kotun Erenköy Heyelanı malzemesinin bulunduğu kotlara göre düşük kotlarda bulunması ve Güzelyalı heyelan döküntüsünün denize yakın konumlanmış olması söz konusu heyelanın ilk oluşum yaşının Erenköy Heyelanına göre daha yaşlı olduğunu göstermektedir.

Çanakkale güneyindeki Erenköy dolayındaki tepelik alanlar heyelan gelişimine uygun bir topografyaya ve yamaç eğimine sahiptir. Bölgenin büyük ve orta ölçekteki depremlerin yaşandığ1, yüksek açılı yamaç eğimlerinin var olduğu bir bölge olması nedeniyle bu alanlarda deprem sonrası heyelan gelişme olasılığı yüksektir. Depremin yarattığ sarsıntı zeminin genleşmesi ve gevşemesini sağlaması, yüzey sularının zemine hızla sızması, heyelan olasılığını artırır.

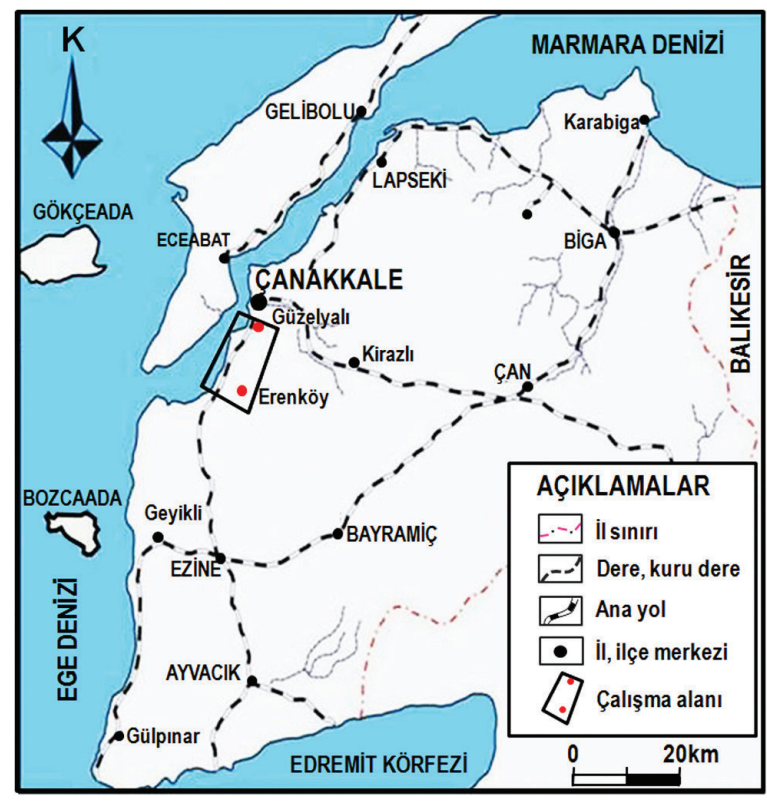

Şekil 1. Çalışma alanının lokasyon haritası.

Figure 1. Location map of study area.

Erenköy ve Güzelyalı köyleri dolayındaki heyelanların bir nedeni deprem ve ikinci üçüncü nedeni ise sırasıyla yüksek yamaç eğimi ve mevsimlik kar ve yağmur suları olmuştur. Ayrıca Çanakkale Grubu kaya birimleri içindeki kiltaşı ve çamurtaşı seviyeleri, diğer nedenlerle birlikte heyelanların oluşumunda önemli bir faktör olmuştur.

\section{STRATIGRAFI}

Üst Miyosen birimleri Çanakkale Grubu ve Ergene Formasyonu olarak bilinmektedir (Siyako, 2006b). Çanakkale Grubu Ergene Formasyonu'nun farkl1 ortamda çökelmiş yanal eşdeğeridir. Pliyosen, özellikle Kuzey Trakya'da geniş yüzlekleri olan Kurcasalih Formasyonu ile temsil edilmektedir (Siyako, 2006b).

\section{Çanakkale Grubu}

$\mathrm{Bu}$ birimin adlanması ilk defa formasyon düzeyinde yapılmış (Şentürk ve Karaköse, 1987; 
Sümengen vd. 1987), Siyako (2006a) tarafindan grup aşamasına çıkartılmıştır.

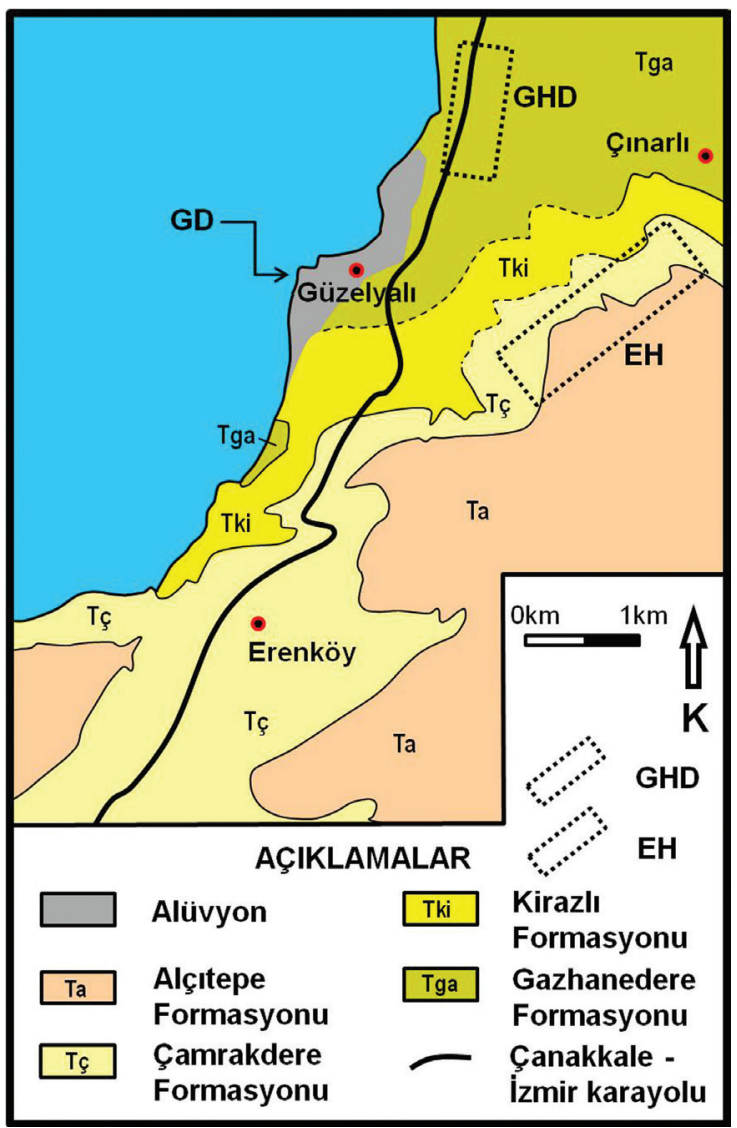

Şekil 2. Çalışma alanının jeoloji haritası (Perinçek ve Karslığlu, 2007; Alkaç ve Perinçek 2009'dan sadeleştirilerek alınmıştır). EH: Erenköy heyelanlarının taç alanı, GHD: Güzelyalı fosil heyelan döküntüsü yol boyu mostra alanı, GD: Güzelyalı Deltası.

Figure 2. Geology map of the area (simplified from Perinçek and Karslıoğlu, 2007; Alkaç and Perinçek 2009). EH: Crown area of Erenköy Landslides, GHD: Roadside outcrop of the ancient Güzelyalı Landslide debris, GD: Güzelyalı Delta.

Çanakkale Boğazı'nın her iki yakasında, Gökçeada ve Bozcaada'da yaşları Geç MiyosenPliyosen aralığında değişen Çanakkale Grubunun; Gazhanedere, Kirazlı, Çamrakdere (=İntepe Üyesi) ve Alçıtepe formasyonları yüzeylemektedir (Şekil 2). Şekil 2'de Gazhanedere, Kirazlı, Alçıtepe ve
Çamrakdere formasyonları için sırasıyla Tga, Tki, Ta, Tç simgeleri kullanılmıştır. Çanakkale Grubu altındaki ve üstündeki birimlerle uyumsuz olup, başlıca kumtaşı, çakıltaşı, kiltaşı, çamurtaşı ve seyrek olarak sığ denizel, lagüner kireçtaşından oluşur. Birimin toplam kalınlıği 800-1400 m arasında değişir, yaşını Okay vd. (1990), Siyako (2006b) Orta-Geç Miyosen olarak vermektedir. Alkaç ve Perinçek (2009) Çanakkale Grubu için birimin stratigrafik konumu ve bölgesel dağılımını dikkate alarak Geç Miyosen -Pliyosen yaşını benimsemişlerdir. Çamrakdere Formasyonu ile birlikte Alçıtepe Formasyonu Trakya Havzası'nda yaygin mostra veren Kircasalih Formasyonunun yanal eşdeğeridir.

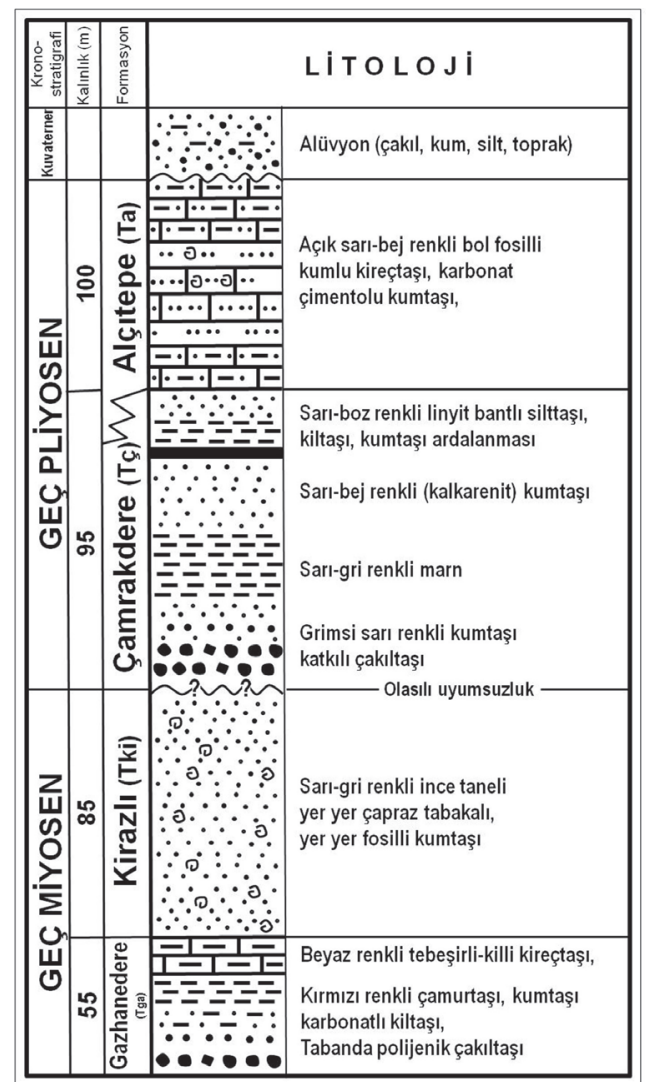

Şekil 3. Çanakkale-Güzelyal1-Erenköy dolayının genelleştirilmiş stratigrafi kesiti. (Alkaç ve Perinçek, 2009 'ten değiştirilerek alınmıştır). Ölçeksizdir.

Figure 3. Generalized stratigraphic section of the Çanakkale-Güzelyall-Erenköy area (modified after Alkaç and Perinçek, 2009). Not to scale. 
Çalışma alanının temelini kırmızı rengin eğemen olduğu çakıltaşı, kumtaşı, marn ardalanmalı Üst Miyosen Gazhanedere Formasyonu oluşturur. Üzerinde bu formasyonla düşey ve yanal geçişli çökelen boz-sarı renkli, çimentolanmamış kumtaşı ile temsil edilen Kirazlı Formasyonu çökelmiştir. Kirazlı Formasyonu üzerinde yer yer kalınlığ 1 0-30 cm arasında değişen kırmızı renkli kılavuz seviye görülmektedir. Alkaç ve Perinçek (2009) bu seviyenin varlığını Üst Miyosen sonu Pliyosen başında havza içerisinde çökelmede kesikliğe yorumlamışlardır. $\mathrm{Bu}$ durumda Çanakkale Grubunu'nun Pliyosen yaşı kesimi Trakya'daki Kırcasalih Formasyonu ile aynı yaşta olacaktır. Kırmızı renkli düzey üzerine sar1-bej renkli ince taneli çakılttaşı, kumtaşı, fosilli marn, kiltaşı, kumtaşı kalkarenit litolojisinden oluşan Çamrakdere Formasyonu (=İntepe Üyesi) çökelmiştir. Tüm bu kırıntılılar üzerine karbonatlı kumtaş1, oolitik kireçtaş1, silttaş1 ve marnlardan oluşan Alçıtepe Formasyonu'nun karbonatları gelir (Şekil 2 ve 3).

\section{Gazhanedere Formasyonu}

Gazhanedere Formasyonu (Şekil 3), kırmızıbej renklidir ve çamurtaşı, kumtaşı, çakıltaşı ardalanması ve bunların birbirine geçiş fasiyesleri şeklinde göze çarpar. Birimin tip mevkide eğemen litolojisi çakıltaşıdır. Ayrıca kumtaşı, silttaşı ve çamurtaşı arabantları vardır. Güzelyalı, Çanakkale yöresinde ise kiltaşı-silttaşı yaygın litolojidir. Çakıltaşı; pembe, bordo renkli olup dağılgandır. Çamurtaşı düzeyleri koyu bordo renkli olup nadiren 3-5 cm'lik kömür bantları içerir. Altındaki daha yaşlı birimlerle olan ilişkisi uyumsuzdur.

Güzelyalı dolayında formasyonun üst kesimlerini oluşturan beyaz renkli marn, kumlu marn oldukça yaygındır. Üstteki Kirazlı Formasyonu'nun kumlu seviyelerine dereceli geçer. Üstteki kumlu seviyelerden geçerek Gazhanedere Formasyonu'nun beyaz renkli marn düzeyine kadar süzülen yüzey suları beyaz renkli marn düzeylerini geçemez. Özellikle yağmurlu sezonda yer alt1 suyu alttaki Gazhanedere Formasyonuna ait kiltaşı ve özellikle beyaz renkli marn üst yüzeyine ulaşınca, bu düzlem boyunca hareket ederek heyelanlara neden olmaktadır. Bölgede gözlenen heyelanların kayma düzlemi beyaz renkli marn seviyesinin üst sınırında yoğunlaşır.

Güzelyalı dolayında yapılan ölçümlerde birimin kalınlığının ortalama $55 \mathrm{~m}$. olduğu görülmüştür.

\section{Kirazlı Formasyonu}

Birimin genel litolojisini kumtaşı oluşturur. Kumtaşı; açık sarı-sarımsı gri, orta-kalın tabakalı, yer yer çapraz katmanlı dağılgan özellikli, inceorta taneli, çok iyi boylanma özelliği gösterir. Bununla birlikte kumtaşı taneleri çoğunlukla kuvars ile temsil olunur. Çalışma alanında Kirazlı Formasyonu daha çok açık sarı renkli olmakla beraber yer yer sarımsı gri renklerde, çimentolanmamış kumtaşı olarak gözlenmektedir (Şekil 2 ve 3). Heyelan yaratma potansiyeli yoktur.

Kirazlı Formasyonu'nun çalışma alanında oldukça yaygın mostraları vardır. Birimin kalınlığı yaklaşık olarak $85 \mathrm{~m}$. dir.

\section{Çamrakdere Formasyonu}

Atabey vd. (2004) tarafından yapılan çalışmada Alçıtepe Formasyonu adı altında üye mertebesinde haritalanmıştır. Siyako (2006b) birim için Çamrakdere Formasyonu adını kullanmıştır. Birimde hakim litoloji çamurtaş1-kiltaşı olup, silttaşı, kumtaşı ve çakılcıklı konglomera ile kalkarenitten oluşmaktadır. Çamrakdere Formasyonu çalışma alanının büyük bir kısmında yüzlek vermektedir. Birimin kiltaş1-çamurtaşı katmanları bölgede gözlenen heyelanların gelişiminde birinci derecede rol oynayan düzeylerdir. 
Çalışma alanında Çamrakdere Formasyonu, alttan üste doğru sarı bej renkli ince taneli kumtaşı ara bantlı çakıllı kumtaşı, üstünde sarı gri renkli fosilli marn, daha üstte gri renkli marn, sarı renkli yer yer_karbonat ve kırılmış kavkı parçaları içeren kumtaşı ve kalkarenit, en üst kısımda da arada kömür bantlarının görüldüğü karbonatlı kumtaşı, fosilli karbonatlı kumtaşı, çamurtaşı kiltaşı, silttaşı, kalkarenit ve marn ardalanmasından oluşmaktadır (Şekil 4). Birim içindeki fosil topluluğu Geç Pliyosen'in altı için karakteristiktir (Yeşilyurt vd. 2007). Çamrakdere Formasyonu (=İntepe Üyesi) bölgede oldukça geniş alanda yüzlek vermektedir. Formasyonun kalınlığ yaklaşık 95 m. dir. kireçtaş1-oolitik kireçtaşı istifi ile birlikte ilk çalışmalarda Alçıtepe Üyesi olarak adlandırılmıştır (Önem 1974). Birim daha sonra Siyako vd. (1989) tarafindan formasyon aşamasına çıkarılmıştır. Birimin egemen litolojisi karbonatlı kumtaşı ve kumlu kireçtaşından oluşur. Kireçtaşları; gri, beyaz renkli, sert, yer yer bol fosilli ve oldukça gözeneklidirler.

Alçıtepe Formasyonu tabanda, Çamrakdere Formasyonu'nun kırıntılıları ile geçişli olarak bejgri renkli, orta tabakalanmalı, çakıllı ve kumlu karbonatlarla başlamaktadır. Birim üstte doğru beyazımsı-gri renkli, ince-orta tabakalı kireçtaş1, kumlu kireçtaşı, gri-boz renkli ince taneli iyi

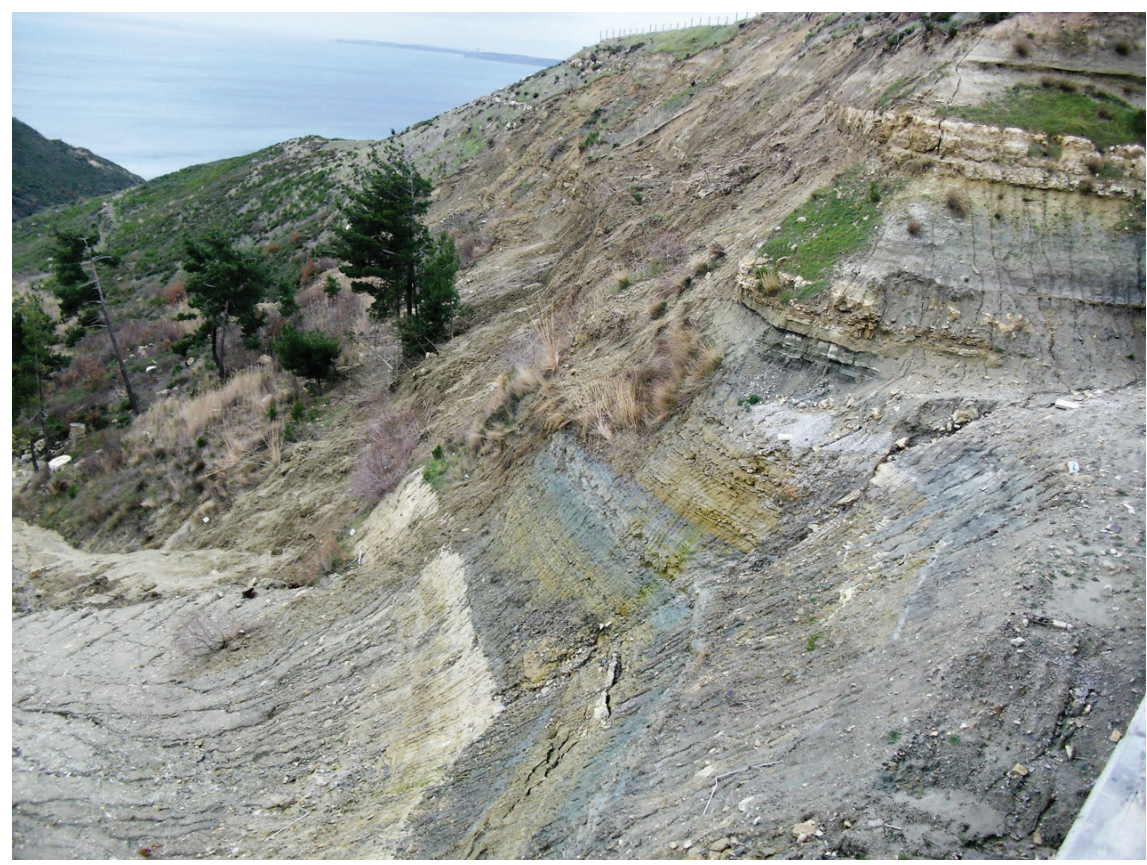

Şekil 4. Çamrakdere Formasyonu'nun Erenköy Viyadük'ü yakınında genel görünüşü. İstif genelde kumtaş1-silttaşı ardalanmalı çamurtaşı ile temsil olunur. Kesitin üst kısmında ise kireçtaşı katkıları görülür.

Figure 4. A general view of the Çamrakdere Formation is near Erenköy Viaduct. The sequence is generally represented by alternating sandstone-siltstone mudstone. Limestone interlayer's are seen on the upper part of the section.

\section{Alçıtepe Formasyonu}

Kirazlı Formasyonu'nun sahil yakını kırıntılı kayaçları üzerinde gözlenen çamurtaşı-kumtaşıçakıltaşı ardalanması ve daha üstteki kumlu çimentolanmamış karbonatlı kumtaşı, silttaşı ve kiltaşı ardalanması şeklinde devam eder. $\mathrm{Bu}$ birimlerin üzerine orta taneli yer yer erime yapıları gösteren karbonatlı kumtaşı çökelmiştir. 
Formasyonun üst seviyelerinde fosil katk11 kireçtaşı düzeyleri hâkimdir. Fosilli kireçtaş1 üste doğru daha ince taneli, sarı-boz renkli karbonatlı kumtaşı, kiltaşı ardalanmasına geçer. Formasyonun en üst kesimlerinde ise karbonat çimento yüzdesi artar, bol oolitli, fosilli iri taneli kumtaşı yer alır. Oolitlerin varlığı yüksek enerjili, çalkanmalı sı̆̆ denizel ya da gölsel çökel ortamına işaret etmektedir (Temel ve Çiftçi, 2002).

Alçıtepe Formasyonu'nun yaşı Geç Pliyosen olarak belirlenmiştir (Yeşilyurt vd. 2007). Birim altındaki Çamrakdere Formasyonu ile geçişli olup, kalınlığı 50-75m arasındadır (Atabey vd. 2004). Çalışma alanında Alçıtepe Formasyonu maksimum 100 m. kalınlık sunar.

\section{Erenköy ve Güzelyalı Çevresinde Oluşan Heyelanların Nedenleri}

Çanakkale〉de Erenköy ve Güzelyalı dolaylarında yakın zamanda olan heyelanları tetikleyen çok sayıda neden bulunmaktadır. Bunlar; 1-Çanakkaleİzmir Karayolunun geçtiği yerlerde yüzeyleyen formasyon/kaya birimleri içindeki killi seviyelerin varlığı, 2-Yol yapımı sırasında yapılan başlıca insan kaynaklı hatalar; yol sanat yapılarında ki hatalar, yüzey sularını kontrol edecek kafa ve topuk hendeği gibi yan yapıların yapılmaması ya da eksik yapılması, yol ve sanat yapılarının yapımı sırasında yamaç eğiminin artırılması, yamacın altının oyulması, yolun geçtiği yerlerde litolojiye gerekli dikkati göstermeden her yerde aynı yöntemin uygulaması, taş duvar yaparken duvarın yüksekliğine ve dış cephe eğimine dikkat edilmemesi, heyelan konusunda yeterli deneyimi olmayan ekiplere iş verilmesi, 3-Bölgedeki ormanın yanmış olması nedeniyle yoğun yağmur/ kar yă̆ışında zemine fazla su süzülmesi, 4Bölgede meydana gelen 3'den büyük depremlerin yer yer tetikleyici rolünün olmasi.

Çanakkale ve yakın dolayı da Kuzey Anadolu Fay Zonu ve kollarının etki alanı içinde kalmakta ve devamlı yükselmektedir. Binlercemilyonlarca yıldır süren bu yükselme akarsuların vadilerini derinleştirmesine neden olmakta, buna bağlı olarak yamaç eğimi artmaktadır. $\mathrm{Bu}$ doğa olgusuna insan hataları da eklenince heyelanlar kaçınılmaz olmaktadır. İnsanların doğaya kısa süre içinde yaptığı müdahale doğanın uzun zaman aralığında kendi kendine sağladığ 1 dengeyi bozmakta ve heyelanların artmasina neden olmaktadır. Heyelanların bazıları, insan eliyle kısa zamanda bozulan doğal dengenin geri kazanılması işleminin bir sonucudur.

Bölgedeki heyelanların çoğu en üsteki Alçıtepe Formasyonu'nun kumlu kireçtaşı ile altındaki çamurtaşı-kiltaşı katkılı Çamrakdere Formasyonu ara düzeylerinde ve Çamrakdere Formasyonu içinde yer alan kumtaşı-kireçtaşı katkıları ile alttaki çamurtaşı sınırında oluşmaktadır. Heyelanların yoğunlaştığı ikinci düzey ise Kirazlı Formasyonu ile bunun altındaki Gazhanedere Formasyonu arasındaki sinırdır. Özetle bölgedeki heyelanların en önemli nedeni Gazhanedere Formasyonu üst kesimindeki beyaz renkli marn ve Çamrakdere Formasyonu içindeki çamurtaşı kiltaşı katkılardır.

\section{Marmara Denizi ve Çanakkale Çevresi Depremleri}

Biga yarımadası ve çevresi geçmişte ve günümüzde deprem aktivitesi oldukça yoğun bir alandır. Kuzey Anadolu Fay Zonu'nun (KAFZ) kuzey kolu Saros Körfezi, Ganos Dağı dolayındaki faylarla temsil edilir. KAFZ'nun orta ve güney kolunu ise Etili, Çan-Biga, Yenice-Gönen, Manyas-Danişment, Lapseki, Sinekçi, Terzialan, Doğruca, Ulubat, Edincik, Pazarköy-Hamdibey-Kalkım, Edremit, Yiğitler, Sarıköy ve Karabiga fayları oluşturur (Gürbüz vd. 2000; Tan vd. 2008; Özden vd. 2009). $\mathrm{Bu}$ fayların sebep olduğu tarihsel depremler sirasiyla 29, 155, 170, 543, 620, 1354, 1440, 1737, 1744, 1855, 1865 ve 1875 yıllarında meydana gelmiş ve büyük yıkımlara neden olmuştur. 
Tekirdağ çukurunu Saros çukuruna bağlayan ve Gelibolu yarımadasını kabaca doğu bat1 yönünde kesen Saroz-Gaziköy Fay1 1912 y1lında birincisi M:6.3, ikincisi M:7.5 büyüklügüünde deprem oluşturarak iki aşamalı olarak kırılmıştır. Aletsel dönemde kayıtlara geçen 1912 SarosŞarköy-Mürefte depremi dışında sırasıyla 1935 Erdek Körfezi (M:6.4) ve Çan-Biga (M:6.3), 1944 Edremit Körfezi-Ayvacık (M:6.8), 1953 Yenice-Gönen (M:7.2), 1964 Gönen (M:5.8), 1971 Edremit-Bakırçay (M:5.5), 1983 Biga (M:5.8), 2006 y1lında Kuşgölü-Manyas (M:5.2) ve Bandırma (M:5.0) depremleri yaşanmıştır (Soysal vd. 1981; Gürbüz vd. 2000; Özden vd. 2009). Saroz-Gazipaşa Fay zonu üzerinde, 1965 'de M:5.6, 1975'de M:6.7, 1985'de M:4.4 olmak üzere 3 yakın tarihli deprem vardır (Şekil 5). Yenice Gönen Fay Zonu üzerinde yapılan aktif tektonik ve paleosismolojik araştırmalar alandaki fayların deprem oluşturma kapasitesi konusunda ve 1953 depremine ait yüzey kırığı hakkında önemli veriler sağlamıştır (Dirik vd. 2008; Kürçer vd. 2008; Kürçer vd. 2016; Özalp vd. 2016). Yakın zamanda yapılan çalışmalar aktif faylar ile ilgili bilinenlerin güncellenmesini sağlamıştır (Emre vd. 2013; Emre vd. 2016; Duman vd. 2016).

Yakın tarihlerde olan depremler sirasiyla 07 Haziran 2012 Tekirdağ doğusunda Marmara Ereğlisi açıkları 5.1 büyüklüğündeki deprem, 8 Ocak 2013 Ege Denizi'nde Bozcaada ve Lemnos adaları açıklarında 6.2 büyüklüğünde deprem (Kiratzi ve Sviggas, 2013), 30 Temmuz 2013 Gökçeada ilçesinde meydana gelen 5,3 büyüklüğündeki deprem (AFAD, 2010), 27 Kasım 2013 merkez üssü Marmara Ereğli olan 4.7 ve 4.0 büyüklüğünde iki adet deprem sayılabilir. Kandilli Rasathanesi'nin verilerine göre 24 May1s 2014'de Gökçeada'nın batısında olan 6.5 büyüklüğündeki deprem (AFAD, 2014) Çanakkale dışında İstanbul ve çevresinde de hissedilmiştir. 2017 y1lında olan Gülpınar-Ayvacık (Sözbilir vd. 2017; Özden vd. 2018) ve Midilli (Kiratzi, 2018) depremlerinin ana şokunu yüzlerce artçı deprem izlemiş, bölgede deprem firtınası yaşanmıştır. Deprem sonrasında Gülpınar dolayında heyelanlar rapor edilmiştir.

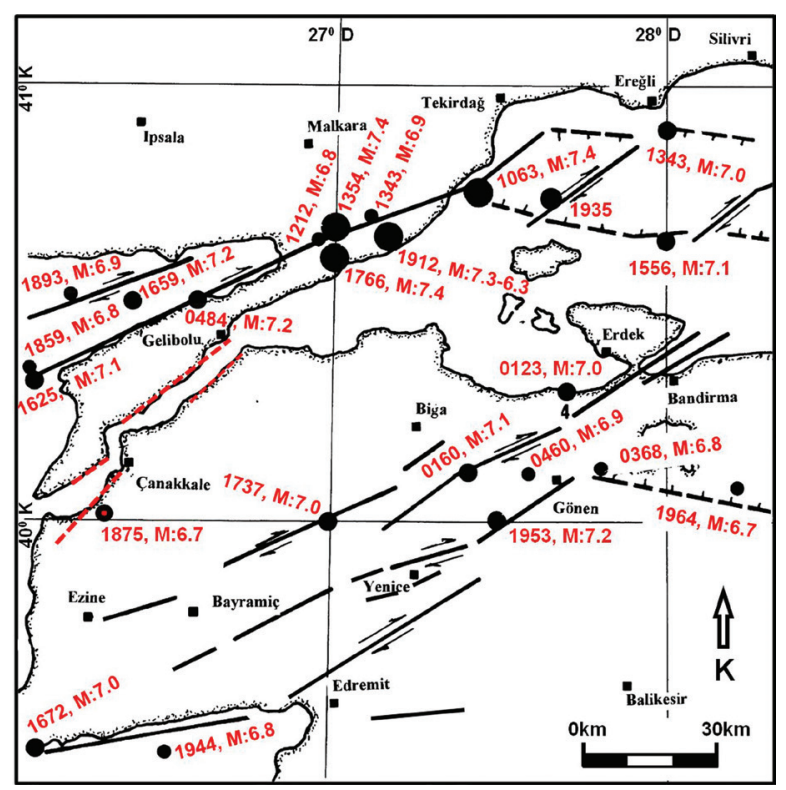

Şekil 5. Çanakkale yakın dolayının aktif faylar, aletsel ve tarihsel dönem depremleri (Gürbüz vd. 2000; Ambraseys, 2002; AFAD, 2010 yayınlarından düzenlenerek alınmıştır). Çanakkale Boğazı kıyılarında yer alan kırmızı kesikli çizgi ile işaretli faylar-çizgisellikler Perinçek (2006) yayınından sadeleştirilerek alınmıştır.

Figure 5. Active faults and historical earthquakes near Çanakkale and its vicinity. (Modified after Gürbüz et al., 2000; Ambraseys, 2002; AFAD, 2010). Faultslineament; marked with red doted line, located along the coast of Çanakkale Strait simplified from Perinçek (2006).

Kuzey Anadolu Fay Zonu'nun güney kolu Biga Yarımadası dolayında en-eşelon dizilimli KD-GB doğrultulu yanal atımlı faylar ile temsil olunur (Emre vd. 2013). Çanakkale kuzeyinde KAFZ'nun unsurları olan faylar bulunur. Söz konusu aktif faylar tarihsel dönemde y1kıc1 depremler yaratmıştır ve gelecekte de yaratama potansiyeli vardır. 1900 yılı ve öncesi ve sonras1 dönemde olan tarihsel depremler Şekil 5 üzerinde işaretlenmiştir (Gürbüz vd. 2000, Ambraseys 
2002). Ayrıca AFAD (2010) arşivinde Çanakkale ili yakınlarında 1875 yılında dört adet deprem kayıtlara geçmiştir (Soysal vd. 1981). Bunların büyüklükleri 1875 Mart ayında M:4.3, 1875 y1lı ortasinda M:6.7, Kasim ayında M:3.7 ve Aralık ayında M:4.3 olmuştur (AFAD, 2010; Tablo 2). Ambraseys (2002), Ambraseys ve Finkel (1991) tarihsel deprem listesinde 1875 ErenköyÇanakkale Depremi'nden bahsetmemektedir. Fakat bu tarihlere yakın olan 6 Mart 1737 depreminin Biga Ezine arasinda olduğunu belirtmişler (Şekil 5) ve 7 büyüklügüündeki bu deprem ile Ezine'nin tümüyle yıkıldığını, depremim Bolayır, Kilitbahir, Bozcaada da tahribata neden olduğunu ve İstanbul'da da hissedildiğini yazmışlardır. 13 Ocak 1873 tarihinde Saros Körfezinde olan deprem (M: 7.1?) Selanik ve İstanbul'dan hissedilmiştir. 13 Ekim 1877 yılinda Marmara Denizinde olan deprem (M: 6.8?) Marmara adasında büyük hasara neden olmuş, deprem İstanbul, Edirne ve Ezine'den güçlü hissedilmiştir (Ambraseys ve Finkel, 1991). Ambraseys (2002) sonraki yayınlarında bazı tarihler üzerinde değişiklik yapmıştır. Dikkati çeken diğer bir deprem ise 1893 yılında Saros Körfezinde olan 6.9 büyüklüğündeki depremdir (Şekil 5). 5 Mart 1875 tarihinde Çanakkale yöresinde Erenköy (eski adı; İntepe) dolayında (yaklaş1k enlem:40 $\mathrm{K}$, boylam:26 ${ }^{0} \mathrm{D}$ ) olan 1875 Erenköy-Çanakkale Depremi’nin büyüklüğü 6.7 olup, 9 şiddetindedir. Deprem sonrası heyelan rapor edilmiştir (AFAD, 2010).

Çanakkale Havzasının işgal ettiği geniş alanda; denizde ve karadan elde edilen sismik ve jeolojik-morfolojik veriler, bu bölgenin Pliyosen'de başlamış olan bir transpresif tektonik rejim etkisi altında kaldığını göstermektedir. Çanakkale Havzasında sonraki evrede havzayı etkileyen tektonik rejim değişmiş, transpresif rejimden transtensif rejime dönüşmüştür (Gökaşan vd. 2012). Çanakkale Boğazından derlenen sismik veriler yorumlanmış ve sismik verilerden elde edilen sonuçlar yayınlanmış, Çanakkale
Boğazı'nın fay kontrolünde gelişmiş bir nehir yatağ1 olduğu belirtilmiştir (Yaltırak vd. 2000; Gökaşan vd. 2008). Çanakkale Boğazı tabanında en genç birimleri etkileyen üç tane yanal atımlı fay saptanmış ve bunlar Kuzey Anadolu Fay Zonu'nun aktivitesi ile ilişkilendirilmiştir. Söz konusu fayların bazılarının Çanakkale Boğazının morfolojisini kontrol eden aktif faylar olduğu belirtilmiştir. Çanakkale Boğazı boyunca alınan Sismik ve batimetri verisi boğazın genelde erozyonla oluştuğunu göstermiştir. (Gökaşan vd. 2010).

Çanakkale Boğazı ve çevresinde jeolojik harita alımı sırasında, boğaz kıyılarının önemli bir kısmının faylarla kontrol edildiğini gösterir yeni veriler derlenmiştir (Perinçek, 2006). Kuzeydoğu-Güneybatı doğrultu fay sistemi kıyıların morfolojisini kontrol eden önemli bir faktördür (Perinçek ve Karslığlu 2007). Fayların kıyıya yakın bulunduğu alanlarda, boğaz kıyıları çizgiseldir. Çanakkale Boğazı; Gelibolu-Eceabat arasında KD-GB doğrultuludur, bu noktadan sonra keskin bir dönüşle güneye yönelir, Çanakkale kenti geçildikten sonra boğaz tekrar KD-GB doğrultusunu kazanır. Çanakkale yöresindeki söz konusu değişimin nedeni, buradaki sıkışma büklümü ile ilgilidir (Perinçek, 2006). Boğazın oluşumunu kontrol eden sağ yanal atımlı fay sistemi, Çanakkale dolayından kuzeye sıçrayarak Eceabat yöresinde sıkışma yapıları oluşturmuştur (Perinçek ve Karslıoğlu 2007). Eceabat yakın güneybatısındaki antiklinal söz konusu sıkışmanın ürünüdür. Boğaz dolayında yüzlekler veren Çanakkale Grubu birimleri genelde düşük açılı eğim gösterir ve kıvrımsız olduğu halde Eceabat dolayında durum farklıdır. Burada antiklinal yapısı dışında, faylar yakınında Kilitbayır-Eceabat arasında tabaka eğiminin 70-80 dereceye çıktığı yerler vardir.

Perinçek (2006) Çanakkale Boğazı çevresinde karadaki fayları haritalamış ve bunların Orta-Geç Miyosen yaşlı gömülü faylar olduğu ve bir kısmının sonradan tekrar aktivite 
kazandığını belirtmiştir. Söz konusu faylar Trakya Havzası'ndaki Alt Miyosen sonrası, Üst Miyosen öncesi yaştaki, bir kısmı Pliyosen de tekrar aktif olmuş Trakya Fay Sistemi ile benzer özellikler gösterir (Perinçek, 1991). Çanakkale Boğazı iki yanında yer alan faylar Emre vd. (2013) tarafindan revize edilen Türkiye'nin aktif fay haritasında çizgisellik sınıfında tanımlanan faylar ile korele edilmiştir. Çanakkale - Güzelyalı yakınlarında olan 1875 Depremi'nin Çanakkale Boğazına paralel uzanan (Perinçek, 2006) gömülü fayların kontrolünde oluştuğu düşünülmektedir.

AFAD (2010) ve Sosyal vd. (1981) 1875 Depremi ile ilgili bilgi içermektedir. AFAD (2010) yayınında ise bölgede yaşayanların aktardığ 1 detay bulunmaktadır. Söz konusu habere ulaşılması, bu makalenin yazılmasını tetikleyen çalışmayı başlatmıştır. Sözü edilen heyelanların nerede olduğu araştırılmış ve heyelanlarının yerlerinin tespiti çok zaman almamıştır. AFAD (2010) da verilen bilgi sayesinde Erenköy heyelanlarının yaşının 1875 olduğu kesin bilinmektedir. Güzelyalı yakınlarında gözlenen heyelanların sebep olduğu deprem ve heyelanın tarihini vermek için eldeki veri yetersizdir. Ancak eldeki veriler Güzelyalı heyelan döküntüsünün göreceli yaşının Erenköy Heyelanından önce olduğunu göstermektedir.

Özetle bu çalışmada Erenköy kuzeydoğusunda tespit edilmiş heyelanla ilgili veriler toplanmıştır. Ayrıca Güzelyalı dolayında fosil heyelan malzemesi-döküntüsü gözlenmiş ve arazi verileri derlenmiştir. Erenköy Heyelanı (EH) ve Güzelyalı Heyelan Döküntüsüne (GHD) ait veriler aşağıda ayrıntılı olarak verilmektedir (Şekil 2).

\section{FOSİL HEYELANLAR}

Deprem sonrası oluşan heyelanlar dünya çapında büyük oranda can kayıplarına ve yapıların tahrip olmasına neden olmaktadır. 1875 ErenköyÇanakkale Depremi geniş bir alanda heyelan olmasına neden olmuştur. Deprem sırasında dik yamaçların olduğu tepelerde kaya düşmeleri ve rotasyonal heyelanlar geliştiğini ve tarım alanların tahrip olduğunu gösterir izler, heyelanların olmasından uzun bir zaman geçmesine rağmen, arazide hala görülmektedir. Ayrıca, arazi gözlemleri heyelanın topuk kısımlarında tarıma uygun düzlüklerin ortaya çıktığını göstermektedir. $\mathrm{Bu}$ heyelan sonucunda can kaybı ile ilgili kayıtlı herhangi bir bilgi bulunmamaktadır. 1875 yılında meydana gelen bu depremin Erenköy yakınlarında $4 \mathrm{~km}$ uzunluğunda bir alanda dağ kayması (heyelan) oluşturduğu, yöre halkının tanıklığı ve yerel basına dayandırılarak kayıtlara geçmiştir (AFAD, 2010 Tablo 2). Arazi çalışmaları sırasında söz konusu heyelanın taç/başlangıç kısmının Erenköy kuzeydoğusunda olduğu saptanmıştır. Kayıtlarda heyelanın taç kısmının uzunluğunun $4 \mathrm{~km}$ olduğu belirtilmekle birlikte, heyelan alanında birbirine komşu taçların toplam yanal uzunluğunun, aralarındaki küçük boşluklarla birlikte, yaklaşık 2500 metre dolayında olduğu belirlenmiştir (Şekil 6).

Taç kısımları birbirine komşu konumlu bu 5 heyelan Erenköy heyelanları olarak adlanmıştır. Bunların taç kısmı geniş bir alanı kapladığ1 ve ormanlık bir bölge olduğu için daha önce çalışan araştırıcılar tarafindan kolaylıkla fark edilememiştir (Şekil 2 ve 6). Güzelyalı kuzeydoğusunda, bulunduğu yerden çok uzakta ve yüksekteki yüzleklerden koparak yuvarlanmış çok sayıda büyük kireçtaşı bloğu içeren heyelan döküntüsü gözlenmiştir. $\mathrm{Bu}$ kireçtaşı blokları Çanakkale Grubunun en üst birimi Alçıtepe Formasyonu'na aittir, blokların bulunduğu yer ise Gazhanedere Formasyonunun mostra verdiği alanlardır. Söz konusu alan; Güzelyalı heyelan döküntüsünün yüzeylendiği bölgedir. Erenköy heyelan sahasında ve özellikle Güzelyalı heyelan döküntüsünün bulunduğu alanda görülen bu kireçtaşı blokları bölgede tarihsel dönemde meydana gelmiş depremlerle tetiklenen heyelanlarla yeniden birkaç kez aktarılmış/yer değiştirmiş olabilir. 


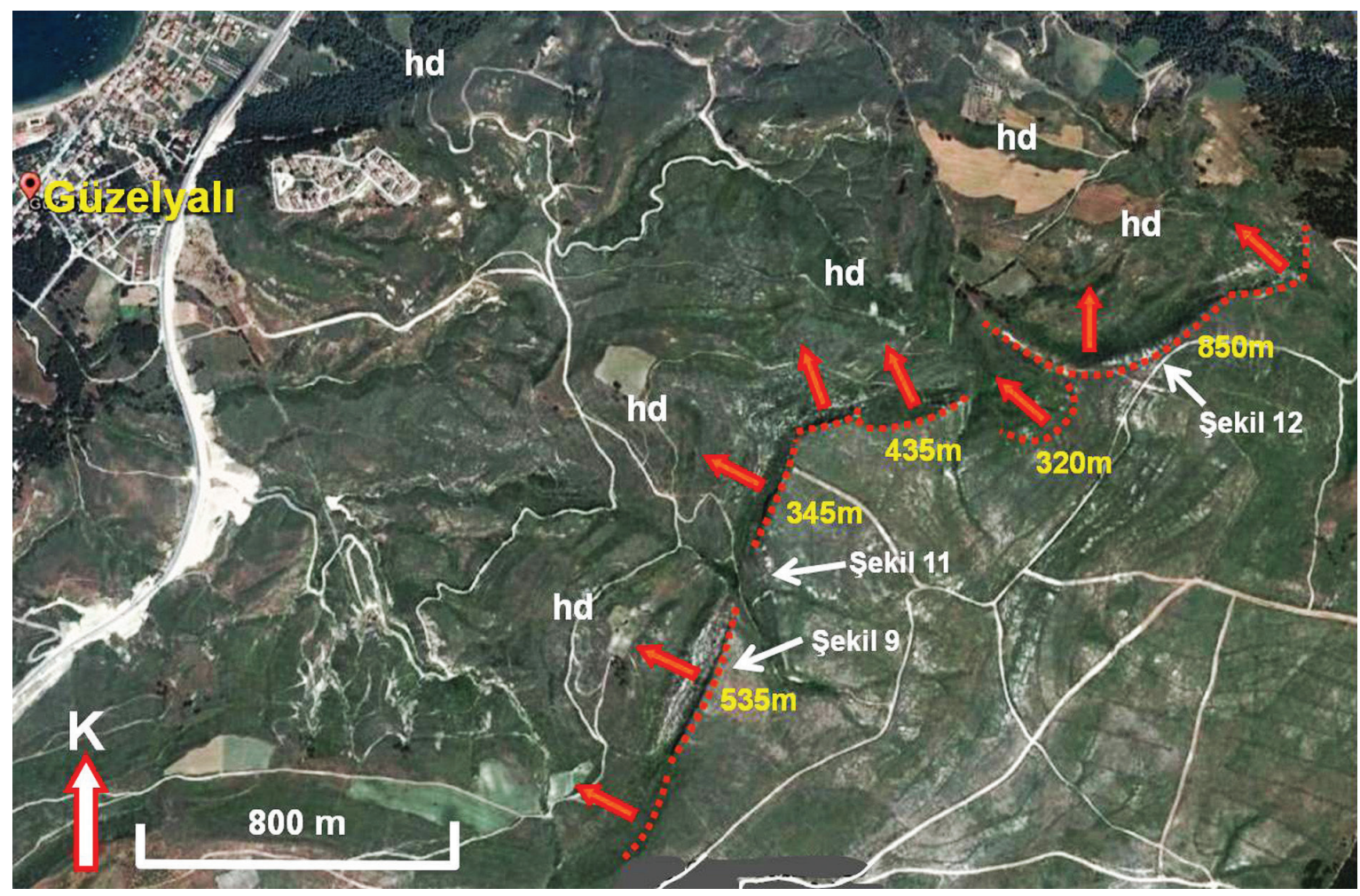

Şekil 6. Çalışma alanında haritalanan Erenköy heyelanlarının GoogleEarth görüntüsü üzerinde yerleri işaretlenmiştir. Heyelanların taç kırıkları kımızı noktalı çizgi ile gösterilmiştir. Sarı rakamlar 5 heyelanın taç kırığının uzunluklarını, oklar heyelan kütlesinin hareket yönünü, hd: heyelan döküntüsü alanlarını göstermektedir. Şekil 9, 11 ve 12'nin yerleri bu görüntü üzerinde işaretlidir. Lokasyon için Şekil 2 ye bakınız

Figure 6. Landslides mapped in the study area are marked on the GoogleEarth image. Yellow number indicating length of crown fracture of five landslides, arrow showing direction of sliding mass, hd: shows areas of landslide debris, Location of figures 9,11 and 12 are marked on the image. For location, see figures 2.

Bu heyelan 1875 Erenköy Depremi'nin etkisiyle Erenköy yakınındaki dağlardan çoğunlukla kaya düşmesi hareketi şeklinde gelişmiştir. Oluşan heyelan büyük olasılıkla, 2013 yılında Erenköy yakınlarında olan heyelanlar gibi, birkaç saat içinde oluşmuştur. Bu belki de Çanakkale dolayında bilinen ve geniş bir alanda görülen en büyük heyelandır. Erenköy yakınındaki fosil heyelanlar iki karakteristik yeryüzü özelikleri ile arazide fark edilmektedir. Bunlar yamacin dibindeki kaya birimlerinin karışık bir görüntüsü sunması ve kaymanın geldiği tepelerde konkav ya da keskin-düz görünüşlü kesik topografyadır. 1875 Erenköy Heyelanı ve öncesi fosil heyelanlarda, kayan kütlenin yayıldığı çokgen alanının uzunluğu yaklaşık 2500 metre, genişliği ise 1500 metre olup, heyelan örtüsünün kapladığ1 toplam alan yaklaşık $3.75 \mathrm{~km}^{2}$ dir (Şekil 2 ve 6). Söz konusu alan yaklaşık 535 futbol sahasının toplamına eşittir. Erenköy heyelan döküntüsü taç kırığının olduğu tepelerden Güzelyalı kuzeyindeki yerleşim alanı ve deniz kıyısına kadar uzanır (Şekil 2 ve 6). Erenköy ve Güzelyalı heyelan döküntüleri içindeki blokların tekrarlanan yatay yer değiştirme mesafesi toplam 1200 ile 1400 m. arasındadır. Çanakkale güneybatısında, GoogleEarth görüntüleri üzerinde kolaylıkla görülebilen bu heyelan Erenköy Heyelanı olarak 
adlanmıştır. Alçıtepe Formasyonuna ait Pliyosen kireçtaş1 ve kumlu kireçtaş1; altındaki birimin çamurtaşı tabaka yüzeyine yakın kopma düzlemi boyunca hareket ederek Güzelyalı Köyü yönünde kaymıştır. Heyelan malzemesinin minimum toplam düşey yer değiştirme miktarı yaklaşık $100 \mathrm{~m}$ olarak hesaplanmıştır. $\mathrm{Bu}$ çalışma ile tanımlanan Erenköy Heyelan döküntüsünün yumuşak topografyası/düzleşmiş morfolojisi ve aşınma miktarı göz önüne alındığı takdirde yakın zamanda hareket etmediği izlenimine varılmıştır.

Erenköy yakın kuzeyinde 2014 yılında ve Güzelyalı dolayındaki fosil heyelan döküntülerinin bulunduğu alanlarda ise günümüzde ve son beş yılda daha küçük boyutlarda bir seri heyelan gözlenmiştir. Güncel ve fosil heyelanlar son 143 y1l ya da daha uzun bir zamanda farklı derecelerde ve hızlarda hareket etmişlerdir.
Şekil 6' da Erenköy yakınlarında saptanan 5 büyük heyelan toplu olarak görülmektedir. Kayan kütle güneydoğudan kuzeybatı yönüne hareket etmiştir. Bunların taç kısımlarındaki kırıkların uzunlukları güneybatıdan kuzeydoğuya sırasıyla 535 m., 345 m., 435 m., 320 m. ve 850 m. olarak ölçülmüştür (Şekil 6). Üçüncü siradaki 435 metrelik ve son siradaki 850 metrelik heyelanın her biri ikişer heyelan olarak ta sayılabilir, fakat bu çalışmada bunlar birbirlerinin devamı oldukları için tek heyelan olarak değerlendirilmiştir. Şekil 7'de taç kısmındaki kırık uzunluğu $535 \mathrm{~m}$. ve 345 m. olan iki heyelanın, Şekil 8'de ise taç uzunluğu $850 \mathrm{~m}$. olan heyelanın yorumlanmış hali detaylı görülmektedir. Taç alanından koparak yer değiştiren heyelan döküntüsü, sonraki yıllarda yamaç aşağıya doğru aşınmaya bağlı olarak taşınmış ve heyelan döküntüsünün bir kısmı

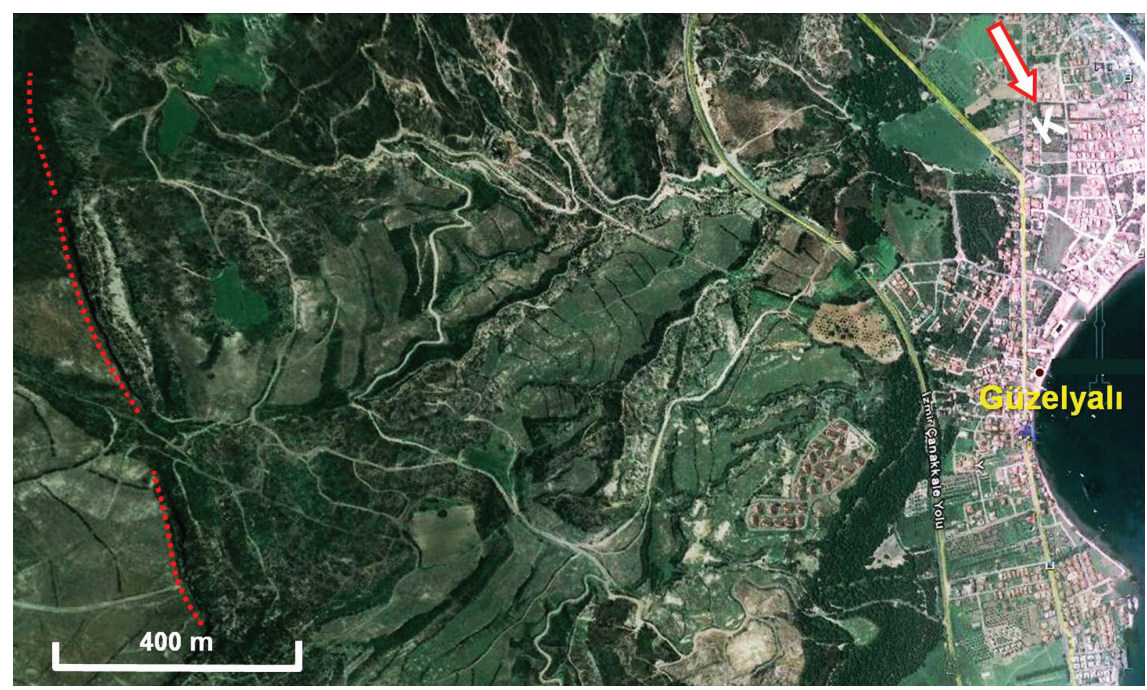

Şekil 7. Güzelyalı yakın doğusundaki, şekilde kırmızı noktalı çizgiyle işaretli taç kırığı uzunlukları 535m 345m arasında olan heyelanların GoogleEarth görüntüsü. Şekilde taç kırığının sağında kalan alanda heyelan döküntüsü düzensiz topografya ile temsil edilir. Heyelan döküntüsü 1875 ve sonrası yıllarda tekrarlanan heyelan ve aşınma ile bulundukları yerden kısmen uzaklaşmıştır. Güzelyalı deltası şeklin sağ üst köşesinde yer almaktadır. Lokasyon için Şekil 6'a bakınız

Figure 7. GoogleEarth image is showing crown crack-main scarp (red dotted line) of landslides located near east of Güzelyall. The main scarp length of the landslides is between $345 \mathrm{~m}-535 \mathrm{~m}$. Landslide debris located right of the red dotted line represented by irregular topography. Subsequent years of 1875 , landslide debris partially has been removed by repeated landslide and erosion. The Güzelyall delta is located at the upper right corner of the image. For location, see figures 6 
bulunduğu alandan uzaklaştırılmıştır. Akaçlama sistemine bakıldığında 1875 Erenköy-Çanakkale Depremi'nde oluşan ve taç kırığı uzunluğu 535 m. ve $345 \mathrm{~m}$. olan heyelanlar Güzelyalı yakınında denize ulaşan derenin akaçlama alanı içinde kalmakta ve heyelanlardan taşınan malzemelerin tamamına yakınının Güzelyalı deltasını beslediği öngörülebilir. $\mathrm{Bu}$ nedenlerle muhtemelen 1875 y1lı ve devamındaki yıllarda Güzelyalı deltasında sedimantasyon artmış ve delta deniz yönünde önemli kazanım elde etmiş olabilir. Akaçlama ağı sınırlı olan Güzelyalı deltasının ek heyelan malzemesi taşınması olmadan bu günkü boyutlarına/büyüklüğüne ulaşması beklenemez. Söz konusu deltada yapılacak detaylı çalışma bu konuda daha sağlıklı bilgiler verecektir.
1875 Depremi ve takip eden heyelanlar bölgenin morfolojisini önemli oranda değiştirmiştir (Şekil 6, 7, 8 ve 11). Takip eden yıllarda alanda süregelen erozyon heyelanın verilerini kısmen silmiştir. Çamrakdere ve Kirazlı formasyonları kapsamındaki kolay aşındırılabilen kumtaşı ve kiltaşı aşınmayı kolaylaştırmış ve heyelan döküntüsü kısmen heyelan alanından uzaklaştırmıştır.

Erenköy yakınındaki eski heyelanlarda yaklaşık 30-35 metre kalınlığındaki Alçıtepe Formasyonuna ait kireçtaşı dilimi yerinden kopup ve irili ufaklı parçalara ayrılarak yamaç aşağıya kaymıştır, kaymanın olduğu yamaç 15 dereceden fazladır (Şekil 9, 10, 11, 12 ve 13a, b). Günümüzde kireçtaşı blokları $1.2 \mathrm{~km}^{2}$ lik bir alana yayılmış olarak bulunmaktadır. Bazı blokların dağıldığ alanın genişliği 385 metreyi bulmaktadır (Şekil 9 ve 10).

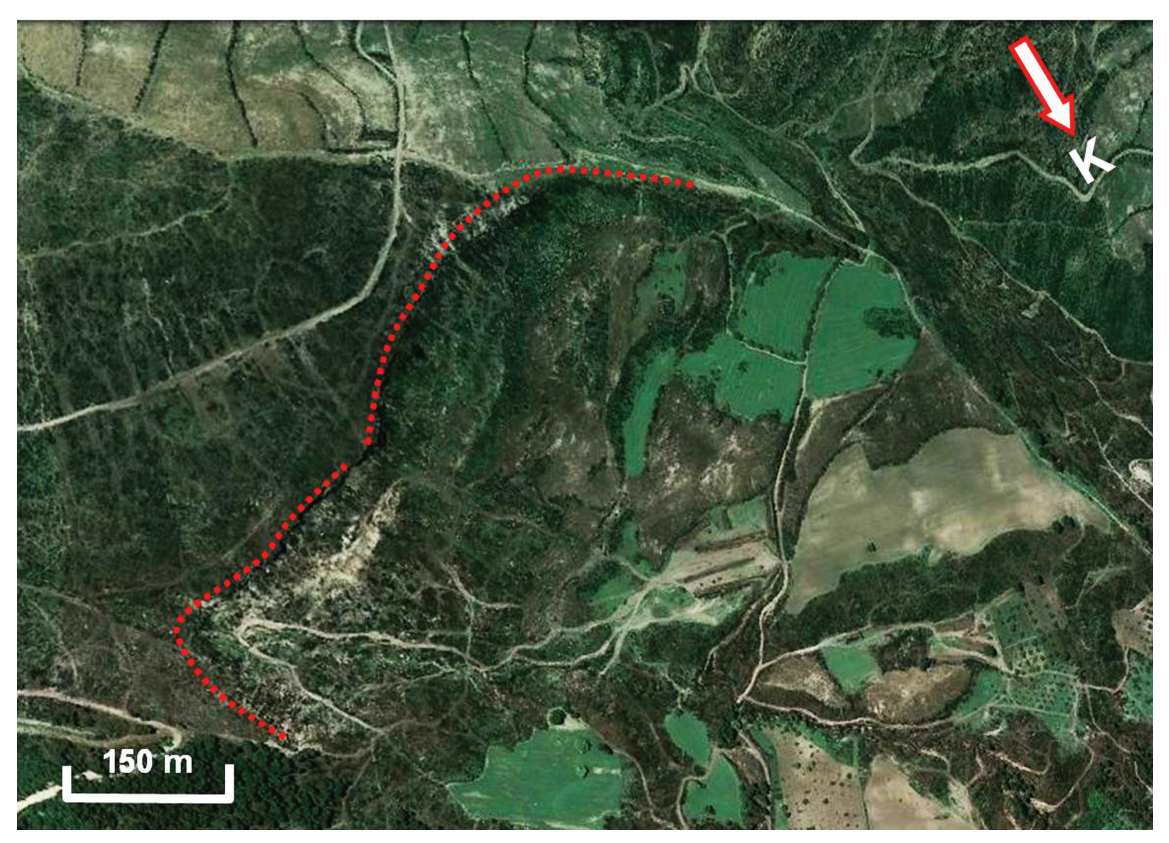

Şekil 8. Kırmızı noktalı çizgi ile işaretli taç kırığı uzunluğu 850 m dolayında olan heyelanın GoogleEarth görüntüsü. Tarlalar heyelanın topuk kısmında yoğunlaşmıştır. Lokasyon için Şekil 6'a bakınız.

Figure 8. GoogleEarth image is showing $850 \mathrm{~m}$ long main crown scarp of landslid, indicated by red doted line. The farmlands are concentrated near the toe of the landslide. For location, see figures 6 


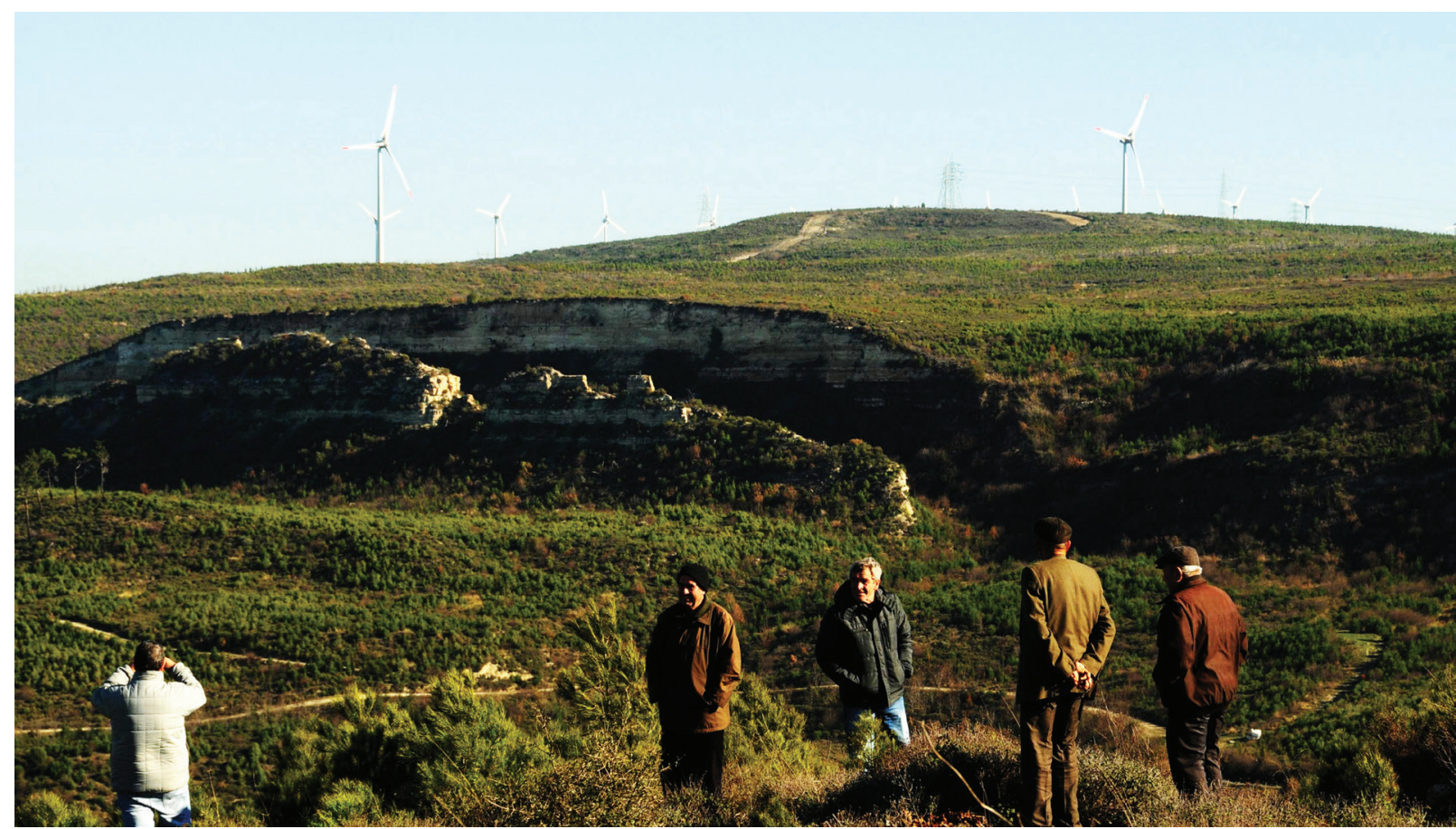

Şekil 9. Taç kırı̆̆ı 535m uzunluğunda olan heyelanın yüksek açılı aynası ve baş kısmı görülmektedir. Şekilde görülen kireçtaşı bloğunun genişliği 385 m'dir. Lokasyon için Şekil 6 ve 7'ye bakınız.

Figure 9. $535 \mathrm{~m}$ long crown fracture, high angle scarp and had of the landslide are seen in photo. Limestone block seen in the figure is up to 385 meters across. For location, see figures 6 and 7.

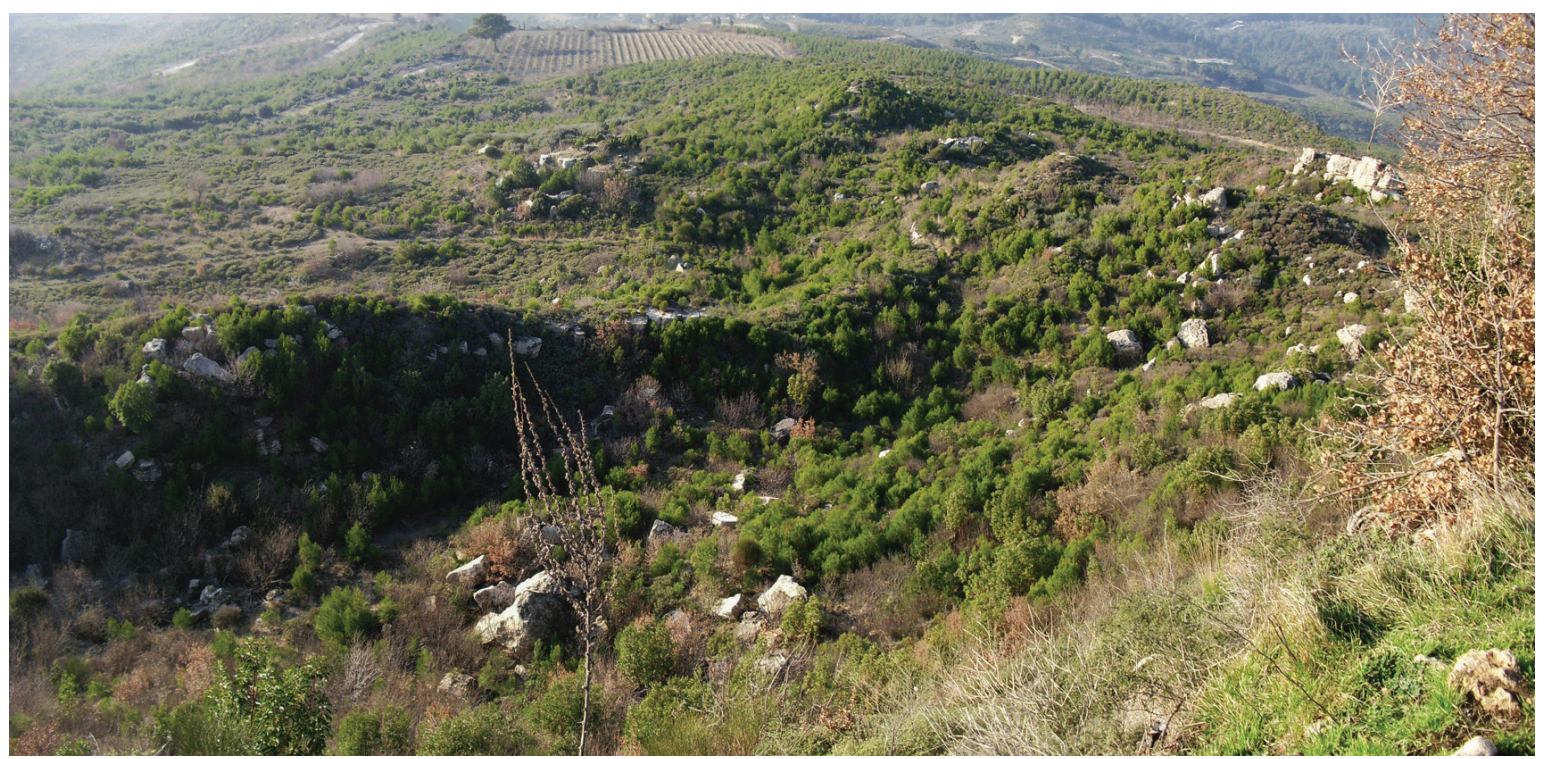

Şekil 10. Taç kırığı uzunluğu 345 m olan heyelanın ayak ve topuk kısmında, kayan kütlenin oluşturduğu düzensiz topografya belirgindir. Lokasyon için Şekil 6'a bakınız

Figure 10. Foot and toe area of $345 \mathrm{~m}$ long landslide showing irregular topography formed by the sliding mass is evident. For location, see figures 6 
Yukarıda sıralanan heyelanların hepsinin taç kırıkları ve baş kısımları Alçıtepe Formasyonunun içinde kalmakta yüksek açılı kayma düzlemi alttaki Çamrakdere Formasyonu'nun çamurtaş1 düzeylerine ulaştığında heyelanın kayma yüzeyi yataya yaklaşmakta düşük açılı olmaktadır. Şekil 9 taç kırığı yaklaşık $535 \mathrm{~m}$ uzunluğunda olan heyelanı göstermektedir. Buradaki heyelanlar dairesel kayma ile kaya devrilmesi türlerinin birleşimi olarak yorumlanabilir. Çalışma alanındaki heyelanın kayma ve birikme zonunda izlenen düzensiz topografya heyelandan 143 y1l geçmesine rağmen belirgindir (Şekil 11 ve 12).

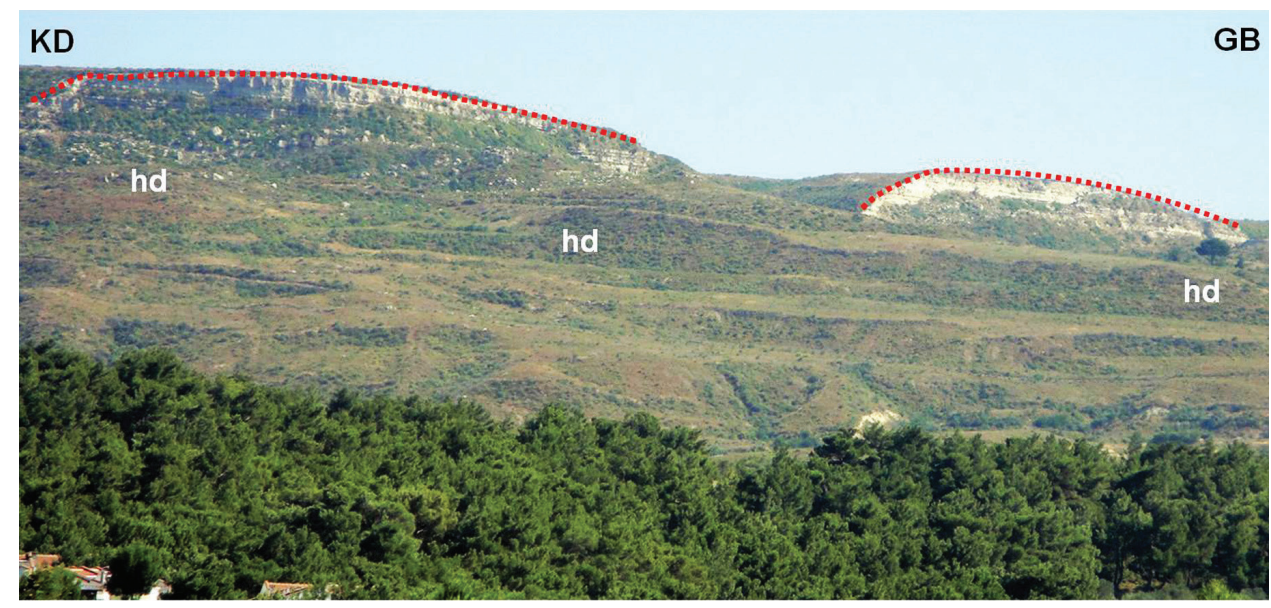

Şekil 11. $535 \mathrm{~m}$. ve $345 \mathrm{~m}$. uzunluğunda taç kırı̆̆ı olan iki heyelanın kuzeybatıdan görünümü. Kırmızı noktalı çizginin alt kesimi ana aynayı, "hd" ise heyelan döküntüsünün yaygın bulunduğu alanları göstermektedir. Lokasyon için Şekil 6 ve 7 ye bakınız.

Figure 11. A view of two landslides with 535 meter and 345 meter long crown cracks from the northwest. Main scarp of the landslide located blow the red dotted line. "hd" indicates areas of landslide debris. For location, see figures 6 and 7.

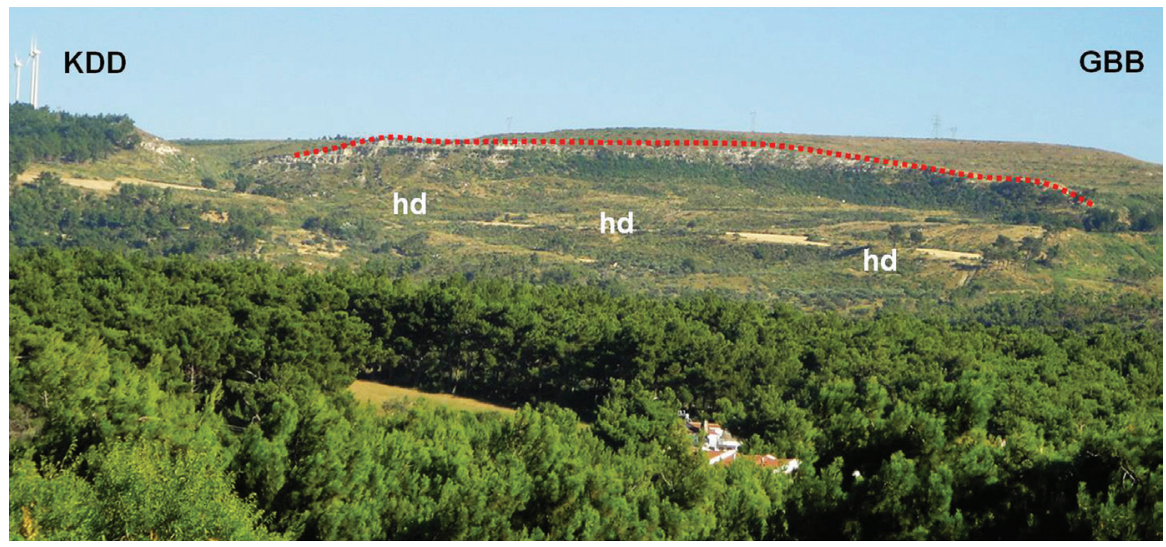

Şekil 12. 850 m. uzunluğunda taç kırığı olan heyelanın kuzeyden görünümü. Kırmızı noktalı çizginin alt kesimi ana aynayı, "hd" ise heyelan döküntüsünün yaygın bulunduğu alanları göstermektedir. Lokasyon için Şekil 6 ve 8'e bakınız.

Figure 12. A view of a landslide with 850 meter long crown cracks from the north. Main scarp of the landslide located blow the red dotted line. "hd" indicates areas of landslide debris. For location, see figures 6 and 8. 
Çalışma alanındaki en büyük heyelanın taç çatlağının uzunluğu 850 metredir. Heyelanın kopma alanı Alçıtepe Formasyonu'nun kireçtaş1 düzeylerinden başlamakta kayma düzleminin önemli bir bölümü ise Çamrakdere Formasyonu çamurtaşı düzeyleri içinde kalmaktadır (Şekil 8, 12, ve 13a, b). Heyelan oluşumundan sonra uzun yıllar geçmesi nedeniyle taç dolaylarında aşınma ile ufalanmış/parçalanmış heyelan malzemesi önemli oranda taşınarak yöreden uzaklaştırılmış ve bu alanı bitki örtüsü kaplamıştır (Şekil 13a, b). Şekil 13b'de görüldügü gibi heyelanın topuk kısmında gelişen düzlükler zaman içinde tarım alanına dönüştürülmüştür.
1875 Depremi'nin yarattığı fosil heyelan alanının batısında deniz içinde de tipik bir denizaltı heyelanı saptanmıştır (Şekil 14). Söz konusu heyelanın deniz tabanında kısmen tutturulmuş çökellerde oluştuğu düşünülmektedir. Denizaltı heyelanının güncel olmadığ 1 kesindir fakat günümüzden kaç yıl önce olduğu net olarak bilinememektedir. GoogleEarth görüntüsünün 7 Mayıs 2011 tarihli olduğu dikkate alındığında, heyelanın en azından bu tarihten önce olduğu söylenebilir. Güzelyalı deltasının güneybatısında kalan heyelanın taç kırığının kıyıya en kısa uzaklığ1 291 metredir. Taç kırığı ile topuk arasındaki mesafe 198 m, heyelanın yan kırıkları arasındaki mesafe ise 185 metredir.
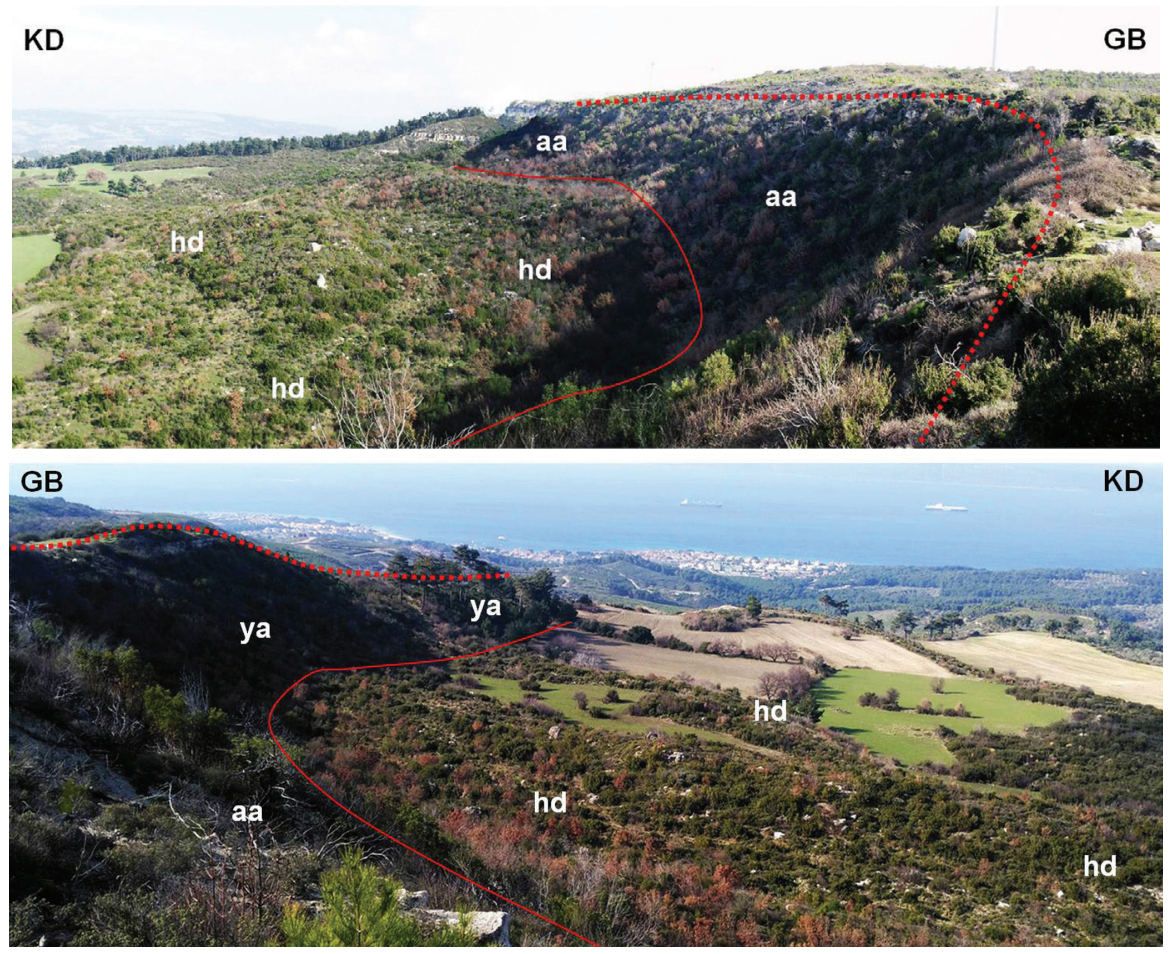

Şekil 13a, b. Fotoğraflarda (a; üsteki, b; alttaki) heyelanın taç, ana ayna ve yan aynası görülmektedir. Heyelan döküntüsü birikme alanında düzensiz topografya gelişmiş̧ir. Kırmızı-çizgiler arasında kalan kesim "aa" ana aynayı ve "ya" yan aynayı, "hd" ise heyelan döküntüsünün yaygın bulunduğu alanları göstermektedir. Tarlaların olduğu alan heyelanın erozyondan korunmuş "ayak" kesimini temsil etmektedir. Lokasyon için Şekil 6 ve 8'e bakınız.

Figure 13a, $\boldsymbol{b}$. The crown, main scarp and side scarp of the landslide are seen in the photographs ( $a$; top, $b$; bottom). An irregular topography developed in the accumulation area. Main scarp "aa" and side scarp "ya" of the landslide located between red lines. " $h d$ " indicates areas of landslide debris. The area where the farmland is located represents the "foot" section of the landslide. For location, see figures 6 and 8. 


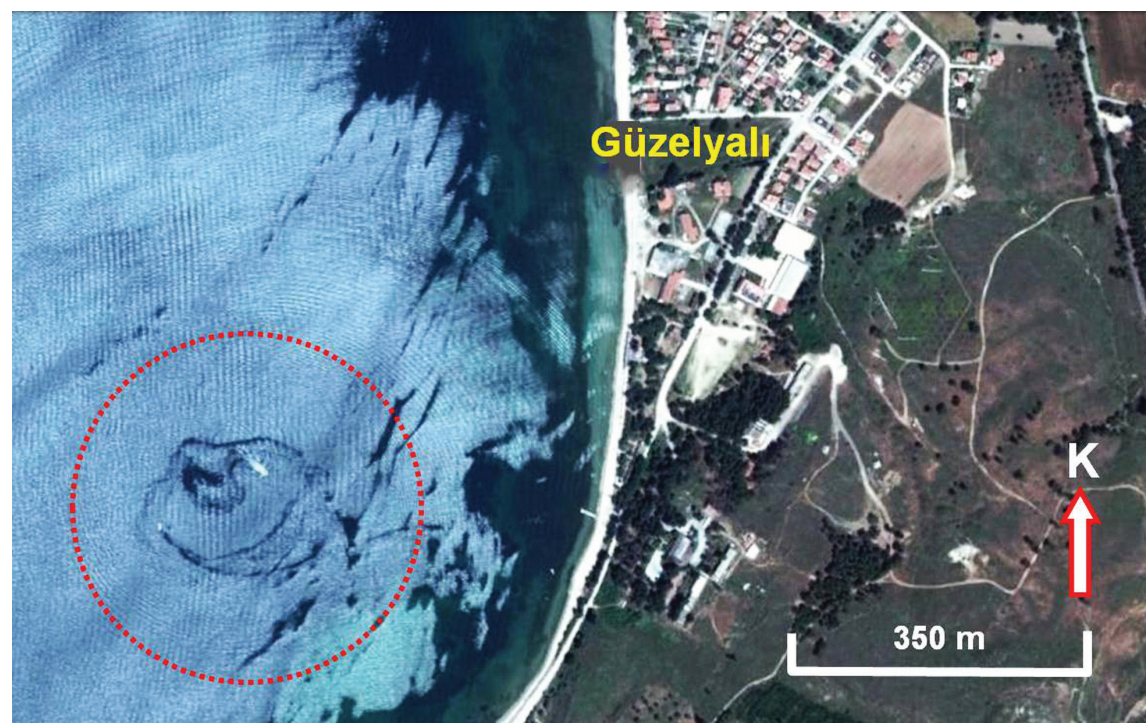

Şekil 14. Güzelyalı yakınındaki denizaltında oluşan heyelanın GoogleEarth uydu görüntüsü. Heyelanın kıyıdan uzaklığı 291 metredir.

Figure 14. The GoogleEarth view of the submarine landslide occurred near Güzelyall. The distance from the coast is 291 meters.

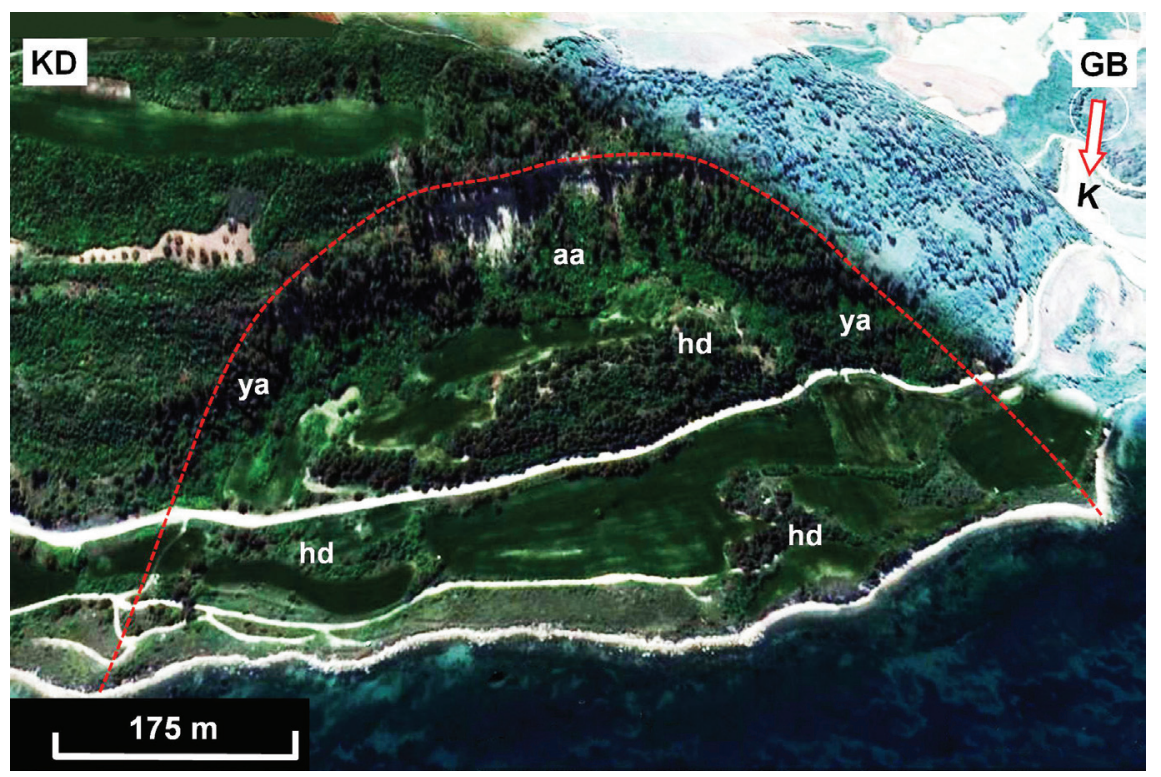

Şekil 15. Erenköy'ün $2.5 \mathrm{~km}$ batısında kısmen aşındırılmış fosil heyelan. Heyelanın ayak ve topuk kısmı denizin içine uzanır. Kırmızı noktalı çizginin alt kesimi ana aynayı, "ya" yan aynayı, "hd" ise heyelan döküntüsünün yaygın bulunduğu alanları göstermektedir.

Figure 15. Partialy eroded fossil landslide located $2.5 \mathrm{~km}$ west of Erenköy. Foot and teo of the landslide stretches into the sea. Main scarp of the landslide located blow the red dotted line. "ya" indicates side scarp, " $h d$ " indicates areas of landslide debris. 
2007 yılında Erenköy kıyılarında arazi çalışması sırasında deniz kıyısında fosil bir heyelan tespit edilmiştir (Şekil 15). Arazi gözlemleri sirasında kıyı boyunca gözlenen arkeolojik buluntular, Arkeolog Kozanlı tarafindan Tunç Çağına (M.Ö. 3000-1200) ait olabileceği belirtilmiştir (Kozanlı, sözlü görüşme, 2008). Bir kısım arkeolojik buluntuların heyelan ve daha sonraki aşınma ve taşınma sonucu deniz içine aktarıldığı saptanmıştır. Sonraki yıllarda "arkeolojihaber" dergisinde çıkan makalede; Prof. Dr. Rüstem Aslan, aynı alanda, bir kısmı su altında gözlenen buluntuları, kayıp bir kent ile ilişkilendirmiştir (arkeolojihaber, 2011). Aslan, çanak ve çömlek kalıntılarının incelemesinin ardından söz konusu bölgedeki yerleşimin MÖ 5000'lere tarihlendiğini işaret ederek; söz konusu alanda buldukları höyüğün denizin 7-8 metre yükselmesi sonucunda yerleşimin su altında kaldığını ve yüzde 90 oranında tahrip olduğunu belirtmiştir (arkeolojihaber, 2011). Bu çalışmaya göre ise arkeolojik buluntuların, yerleşim alanında olan heyelan sonrası, yüksek kotlardan deniz kıyısına ve deniz içine aktarıldığı belirlenmiştir. Deniz içinde bulunan 7000 yıl öncesine ait olduğu iddia edilen çanak-çömlek heyelan ile buraya aktarılmıştır, olayın deniz seviyesi yükselmesi ile ilgisi yoktur. $\mathrm{Bu}$ alanda görülen fosil heyelan Erenköy heyelanları ile yaşıt ya da daha eski olabilir. Güzelyalı heyelan döküntüsünü üreten heyelanlar ile yaş ilgisi yoktur, onlardan çok daha gençtir.

\section{Güzelyalı Çevresindeki Fosil Heyelanlar}

Güzelyalı Köyü girişine yakın alanda muhtemelen yüzlerce y1l önce oluşmuş kaotik ve parçalanmış moloz görüntülü, geniş alanlara yayılmış eski heyelan döküntüsü bulunmuştur (Lokasyon için Şekil 2 ye bakınız). Çanakkale İzmir yolunun genişletilmesi sırasında yol yarmasında yapılan gözlemlerden fosil heyelan malzemesi ile ilgili önemli bilgiler sağlanmıştır. Şekillerdeki fotoğraflar 3 Ağustos 2011 - 20 Ağustos 2011 tarihleri arasında, Çanakkale-İzmir karayolunun yapımı sürerken çekilmiştir. Aradan geçen süre içinde yağmur ve diğer etkenlerle fotoğraflardaki heyelanın iç dokusunu gösteren netlik kısmen silinmiştir. Yol yarmasında Çanakkale Gurubunun farklı formasyonlarına ait birim ve litolojiler karmaşık olarak bulunmaktadır (Şekil 16a, b ve $17 \mathrm{a}, \mathrm{b}, \mathrm{c})$. Bazen heyelan malzemesi içindeki düzenli çizgisellikler-süreksizlikler yanıltıcı olmakta, fay görüntüsü vermektedir (Şekil 17c). Son yıllarda Güzelyalı dolayında olan krip tipindeki bu heyelanlar (Yiğitbaş vd. 2005; Baba vd. 2005; Kürçer vd. 2005; Tatar vd. 2011) bu makale dışında tutulmuştur. Yavaş akma türündeki heyelanı (krip) işaret eden en önemli verilerden biriside gövdeleri eğik duran çam ağaçlarıdır. Güzelyalı kuzeydoğusunda sahildeki dik yamaçlı kıyılar; sürmekte olan yavaş akma (krip) tipi heyelanların varlığının ikinci bir kanıtıdır. Günümüzde ve önceki son 14 yılda meydana gelen krip tipindeki heyelanlarda akan malzeme eski heyelan döküntüsünün tekrar akması şeklinde gelişmektedir. Yamaç aşağıya akan eski/fosil heyelan döküntüsünden oluşan toprak örtüsü, deniz kıyısında da sürekli toprak akmasına neden olmaktadır.

Güzelyalı dolayında olan yeni heyelanlar dikkate alındığında fosil heyelanlardan bazılarının da mevsimsel olduğu söylenebilir. Toprak içindeki nem miktarı ve sıcaklık mevsimlere bağlı olarak yağmurlu aylarda değişmektedir. Nemin artması deprem tetiklemesi dışında fosil heyelanların sebeplerinden biri olmuş olabilir. Söz konusu alanda bulunan fosil heyelan döküntüsü gravite kontrolünde birkaç kez yer değiştirmiştir. $\mathrm{Bu}$ olay bir seferde olmamış, zaman içinde defalarca tekrarlanmıştır. Fosil heyelan döküntüsünün iç dokusunun daha karmaşık halde görülmesi heyelandaki tekrarlanmayı işaret eden verilerden bir tanesidir (Şekil 16a, b ve 17a, b, c).

Güncel heyelanların oluşumu sırasında hareket eden kütlenin fosil Güzelyalı heyelan döküntüsü 
olduğu bu çalışmayla netleştirilmiştir. Bu sonuca varmamızı sağlayan en güvenilir veri Çanakkaleİzmir karayolunun genişletilmesi sırasında yol yarmasında ortaya çıkan fosil heyelan döküntüsü yüzlekleridir. Ayrıca Tatar vd (2011) tarafından hazırlanan güncel heyelan raporunda fosil heyelan döküntüsü ile ilgili bilgi bulunmaktadır. Şekil 2'de verilen jeoloji haritasında Güzelyalı heyelan döküntüsünün olduğu alan Gazhanedere Formasyonu olarak haritalanmıştır. Bu gözlemler fosil heyelan döküntüsü oluşturan kütlenin
Gazhanedere Formasyonu bünyesinde yer alan beyaz ve bordo renkli killi düzeyler üzerinde kaydığını göstermektedir. Güzelyalı fosil heyelan döküntüsünün Gazhanedere Formasyonu üzerindeki örtüsü 2017 yılın son aylarında denize doğru hareketini sürdürmüş ve Güzelyalı Köyü girişindeki yolda ve kaldırımlarda yüzeysel bozulmalara, kırılmalara, kabarmalara neden olmuştur. Önleyici çözümler üretilmediği takdirde yüzeydeki bu deformasyonlar devam edecektir.
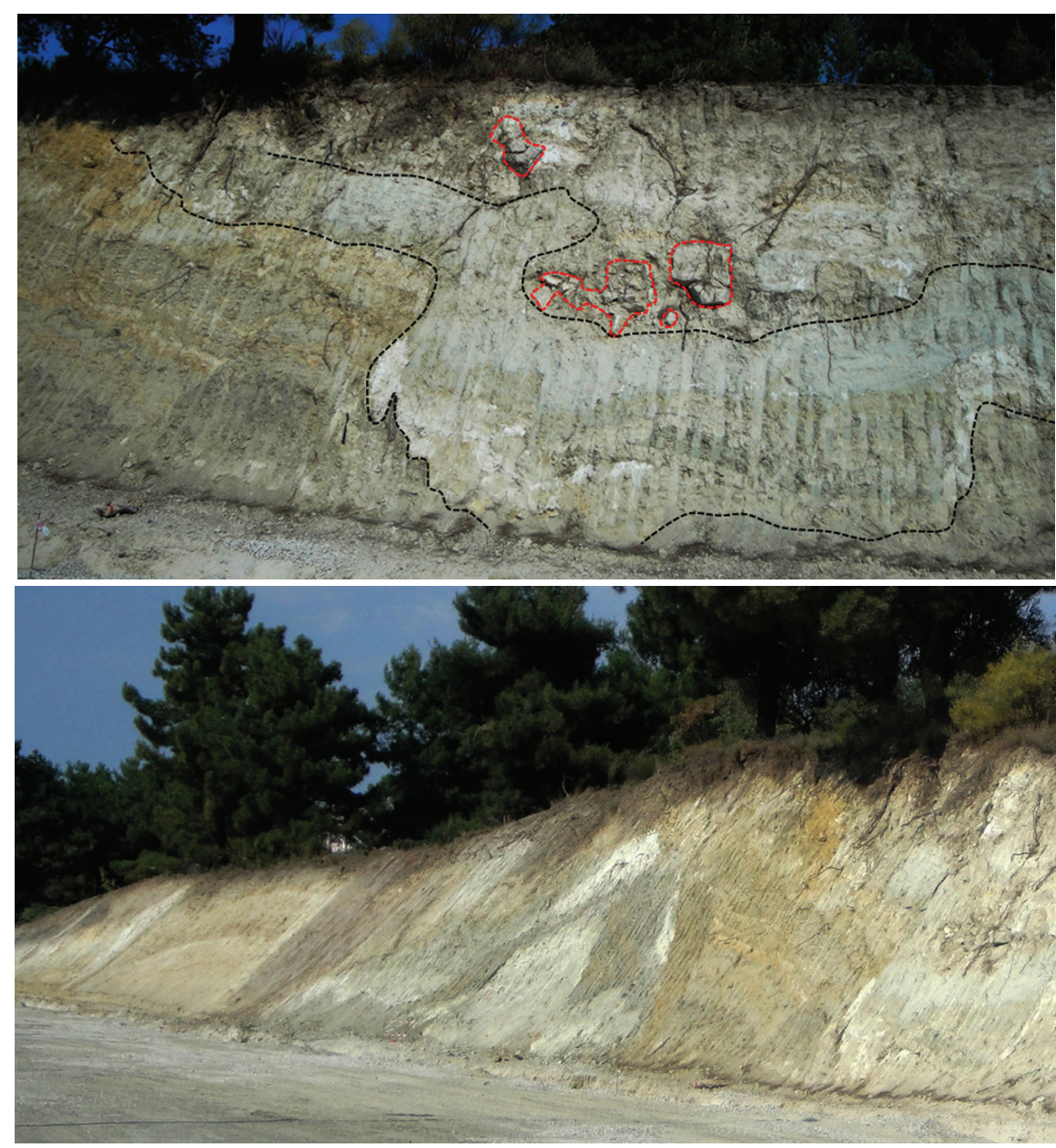

Şekil 16a, b. Heyelan döküntüsü içinde farklı litolojiler birlikte görülür (a; üsteki, b; alttaki foto). Çamurtaşı-kiltaş1sittaşı karışığından oluşan hamur içinde iri çakıl-blok boyutlarında kireçtaşı parçaları görülür (üsteki şekilde kırmızı ile işaretli)

Figure 16a, b. Different lithologies coexist in the landslide debris ( $a$; top, $b$; bottom photo). The coarse gravel-block size pieces of limestone fragments are seen in the matrix formed by the mixture of mudstone-claystone-siltstone (marked with red in the top figure) 

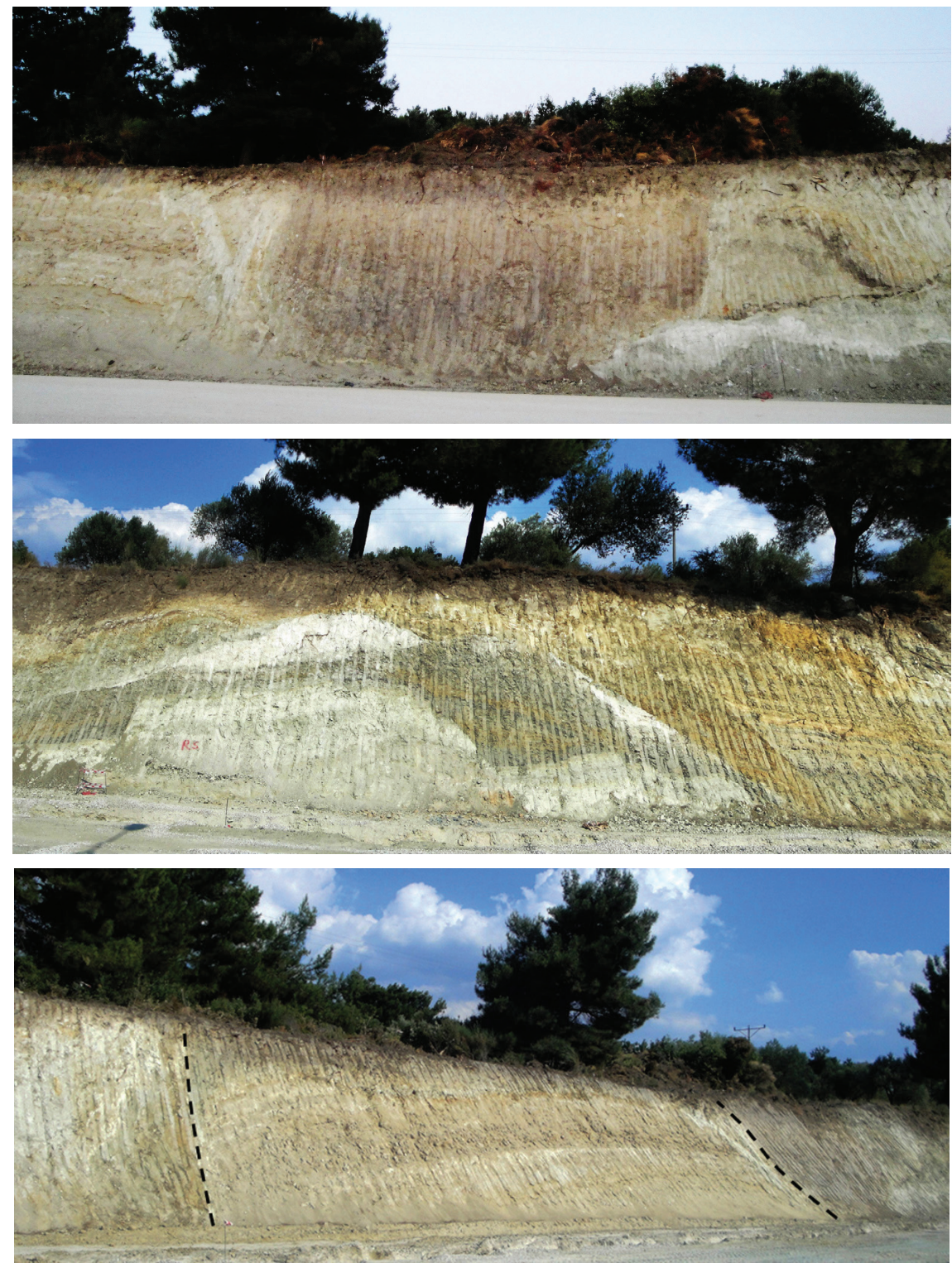

Şekil 17a, b, c. Kaotik ve parçalanmış heyelan döküntüsünde yanal yönde süreksizlik belirgindir (a; üstteki, b; ortadaki, c; alttaki foto). Ortadaki şekildeki beyaz renkli litoloji Çanakkale grubunun en alt birimi olan Gazhanedere Formasyonuna aittir. Heyelan döküntüsü içinde görülen bazı süreksizlikler fay görüntüsü vermektedir.

Figure $17 \boldsymbol{a}, \boldsymbol{b}, \boldsymbol{c}$. Lateral discontinuity is evident within the chaotic and fragmented landslide debris ( $a$; top, $b$; middle, c; bottom photo). The White colored lithology in the middle figüre belongs to Gazhanedere Formation, which is the lowest unit of Çanakkale group. Some of the discontinuities seen in the landslide debris give a fault impression. 
Güzelyalı yakınındaki heyelan döküntüsü içinde kireçtaşı blokları gözlenmektedir. Bunlar çevrelerindeki kayaç türlerine göre daha dayanımlı olduklarından toprak yüzeyinde belirgin görüntü verirler (Şekil 16a ve 18). Kireçtaşı blokları Çanakkale Grubu'nun enüstekibirimi olanAlçıtepe Formasyonu'na aittir. En üstteki birime ait bu bloklar tekrarlanan heyelanlar ile alt birimlerden, Çamrakdere ve Kirazlı formasyonlarından türemiş bir matriks içinde de görülebilmektedir. Eski heyelanların olduğu tepelerden Güzelyalı dolayına kadar olan alan genellikle eski heyelan döküntüsü ile örtülüdür (Şekil 7, 11, 12 ve 13a, b). Bazı yerlerde ise heyelan döküntüsü tümüyle aşınmış alttan Çanakkale Grubu'nun Çamrakdere ve Kirazlı formasyonuna ait mostraları çıkmıştır. Güzelyalı heyelan döküntüsünün üzerinde kaydığ1 kaya birim ise Gazhanedere Formasyonunun killi düzeyleridir. ilgili veriler sunulmuş, tanımlanan heyelan Erenköy Heyelanı olarak adlanmıştır.

Heyelanlar güneydoğudan kuzeybatı yönüne doğru hareket etmiştir. 1875 Erenköy-Çanakkale Depremi ve takip eden heyelanlar bölgenin morfolojisini önemli oranda değiştirmiştir. 1875 Depremi'nin Erenköy Heyelanının sorumlusu olduğu ve heyelanında heyelan döküntüsü içinde dağılmış kireçtaşı bloklarının yüksek kotlardan deniz kıyısındaki Güzelyalı yakınlarına taşınmasına neden olduğu bu çalışma ile ortaya çıkarılmıştır. Heyelan döküntüsü ve içindeki bloklar alttaki killi seviyeler üzerinde kolaylıkla yer değiştirmiştir.

Çanakkale sınırları içinde bilinen en büyük tarihsel heyelan şehir merkezinin güneybatısında Erenköy-Güzelyalı dolayındaki heyelandır. Söz konusu heyelan 143 yıl ve daha önce oluşmuş

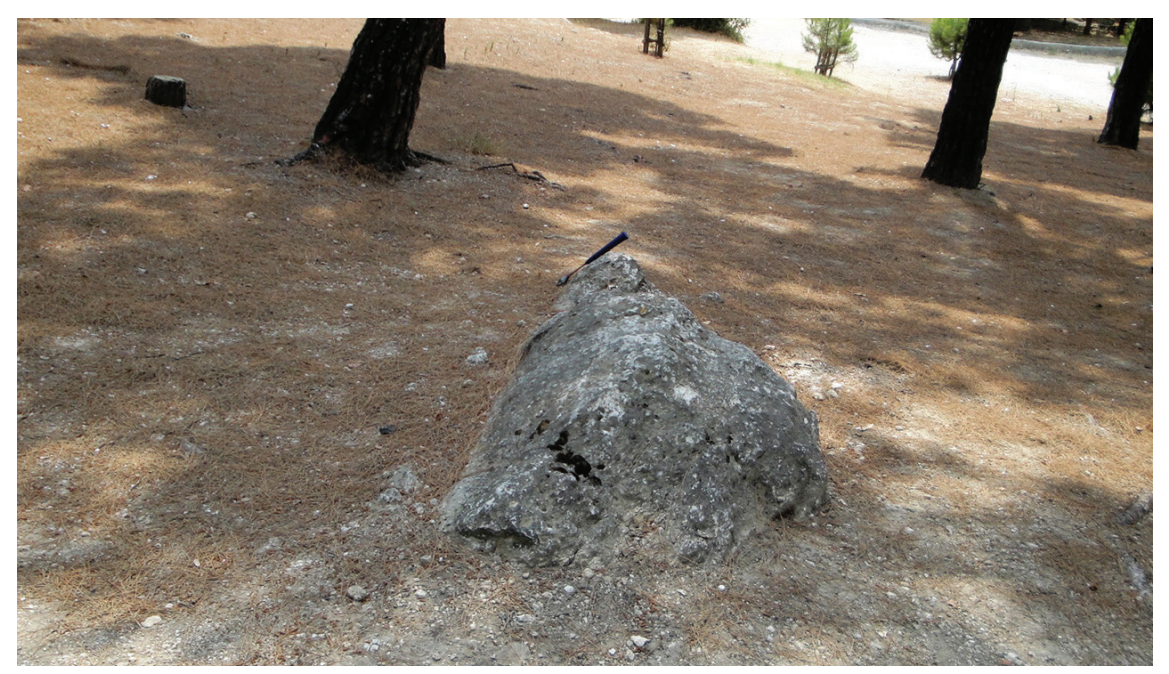

Şekil 18. Heyelan döküntüsü içinde Alçıtepe Formasyonuna ait değişik boyuttaki kireçtaşı bloklarından birinin görüntüsü.

Figure 18. The limestone blocks seen in different sizes within the landscape debris belong to the Alçıtepe Formation.

\section{SONUÇLAR}

$\mathrm{Bu}$ çalışma ile Erenköy yakınında tarihsel dönemde oluşmuş heyelan ortaya çıkarılmış ve Güzelyalı dolayında fosil heyelan döküntüsünü betimlemiştir. Erenköy yakınındaki heyelanlarla olsa da çok geniş bir alanı kapladığı için heyelan sonrasında süregelen aşınma, ayrışma ve bozuşma heyelanın belirtilerini tümüyle ortadan kaldıramamıştır. En dikkati çeken kanıt heyelan döküntüsü içindeki Pliyosen yaşlı 
kireçtaşı blokları ve taç kısmındaki kırıklardır. Çamrakdere ve Kirazlı formasyonları içindeki kolay aşındırılabilen kumtaşı ve kiltaşı düzeyleri erozyonu kolaylaştırmış ve heyelan malzemesi önemli oranda heyelan alanından uzaklaşmıştır.

Güzelyalı dolayında eski heyelan döküntüsü ve bağımsız kaya parçaları tanımlanmıştır. Güzelyalı Köyü'ndeki eski heyelan döküntüsü ve ilgili heyelanların ilk oluşum yaşı Erenköy Heyelanından öncedir.

Doğu Güzelyalı alanında, Gazhanedere Formasyonu üzerinde bulunan eski heyelan döküntüsü üzerinde inşa edilen evler 3-5 y1l arayla deniz yönünde hareket ettiği için sürekli hasar görmektedir. Bu tekrarlanan krip tipindeki heyelanın nedeni yerleşim alanının oturduğu zemindeki eski heyelan döküntüsüdür. Kayma düzlemi Gazhanedere Formasyonunun killi seviyeleri ile heyelan döküntüsü arasında kalmaktadır.

Güzelyalı Köyü yakınındaki heyelan döküntüsünün çok sayıdaki tekrarlanan heyelanlar tarafindan oluşturulduğu düşünülmektedir. $\mathrm{Bu}$ olayların geçmişte birkaç yüz yıl içinde olduğu sanılmaktadır ve yakın zamanda da tekrarlanmıştır. Heyelan döküntüsünü de içeren toprağın kalınlığı bazı alanlarda 10 metreye kadar ulaşmaktadır. Birbiri arasında belki de yüzyıllar olan çok sayıdaki kaymalardan bazıları muhtemel bazı tarihsel depremlerle tetiklenmiş olabilir. Şu anda cevabı bilinmeyen ve araştırılması gereken soru; geçmişte kaç tane büyük heyelan olmuştur ve bunların arasında kaç yıl vardır. Kayma düzlemlerinin bazıları Alçıtepe Formasyonu tabanında veya Çamrakdere Formasyonu'nun üst sınırına yakın kesimde veya Çamrakdere Formasyon içinde yer alan kiltaşı-çamurtaşı ara katkıları boyunca olmuştur. Güzelyalı alanında ise kayma düzlemi Gazhanedere Formasyonu en üst seviyesinde, çoğunlukla toprak düzeyi tabanındadır ve toprak tarihsel heyelan döküntüsü ile temsil edilir. Burada kayma düzlemi açısı düşüktür.
$\mathrm{Bu}$ çalışma kapsamında Çanakkale Grubu içinde Kirazlı (Geç Miyosen) ve Çamrakdere (Pliyosen) formasyonları arasında tanımlanan uyumsuzluk, ilk defa bu makalede kayıtlara geçmektedir (Alkaç ve Perinçek, 2009).

\section{EXTENDED SUMMARY}

There are two primary categories of causes of landslides: natural and human caused. Sometimes, landslides are caused, or made worse, by a combination of the two factors. Natural Occurrences has three major triggering mechanisms that can occur singly or in combination (1) water, (2) seismic activity, and (3) volcanic activity. Effects of these causes vary widely and depend on factors such as steepness of slope, morphology or shape of terrain, soil type, underlying geology, and whether there are people or structures on the affected areas. Humans contribute to the occurrence of landslides. Disturbing or changing drainage patterns, destabilizing slopes, and removing vegetation are common human-induced factors that may initiate landslides (Highland and Bobrowsky 2008, Sarker and Rashid, 2013). It is important for engineers and geologists to evaluate slope stability and any landslide threat during development assessments so that effective and timely remedial measures can be implemented. Understanding the Earth's more violent events will help us be prepared, repeated landslides threaten.

Ancient landslides near Erenköy-Güzelyalı villages in Çanakkale have been investigated and evidence for the landslide collected. The remnants of Erenköy landslides are one of the Çanakkale regions best-preserved examples of a huge landslide that followed an earthquake dated 1875. Ancient landslide is located near Erenköy in southwestern Çanakkale and it has been called Erenköy Landslide. These landslides had migrated from southeast to northwest. In addition, also ancient landslide debris and loose 
rock near Güzelyalı identified. Ancient Güzelyalı's landslide debris and related landslide is older than Erenköy's landslide.

Many mountainous areas like south of Çanakkale around Erenköy that are vulnerable to landslides. Çanakkale area have also experienced at least high to moderate rates of earthquake occurrence in recorded times. The occurrence of earthquakes in steep landslide-prone areas greatly increases the likelihood that landslides will occur, due to ground shaking alone or shaking-caused dilation of soil materials, which allows rapid infiltration of water. It is obvious that addition to the earthquake; the causes of ancient landslides in Erenköy and Güzelyal area were in general related to instabilities in slopes. The 1875 ErenköyÇanakkale Earthquake caused widespread land sliding and other ground failure, which probably caused most of the agricultural loss due to the earthquake. Widespread rock falls also are caused by loosening of rocks as a result of ground shaking. Over 143 years ago, side of the mountains near Erenköy affected by a rockslide type of landslide. A giant landslide most likely happened in a few hours. Total occupation area of the sliding slab and crown cracks were about a 2500 in length and nearly 1500-meter-wide and had a surface area of about 3.75 square kilometers including ancient landslide debris that is predating 1875 landslide. This is equal to the sum of 535 football fields. Debris from the slides extends to Güzelyal Village at the base of the slope and spread to the coastline. Some material in the slide had a travel distance of over 1200 to 1400 meters. Ancient landslide complex around Erenköy-Güzelyalı area has the distinction of having one of the largest, landslides in Çanakkale. Today the area is made up of a series of smaller active landslides, which have shown varying degrees of movement during the last 143 years or more.

1875 landslide was a dramatic, punctuated affair that greatly altered the landscape (Figures 6, 7, 8, 11 and 12). Post 1875 erosion activity have partially erased much of the evidence of landslide. The abundance of easily eroded sandstone and mudstone within Çamrakdere and Kirazl formations increase erosion rate. Most of the landslide debris easily removed from the area. Erenköy landslide debris have rounded, subdued morphology suggestive of inactivity and recent stability.

Although this landslide occurred over 143 years ago, it was so large that weathering and erosion have not yet obscured all the evidence. The most revealing features of the slides are a massive block of Pliocene age limestone and crown cracks. Ancient landslides near Erenköy have been noticed by land features bearing two hallmark characteristics. These are: a jumbled assortment of rocks at the base of a slope, and a cuplike or sharp-straight topography cut out of the hills where the slide might have come from. The slide occurred when a large slab of limestone, about 30-35 meters thick, became detached and slid down a slope that had an average slope of more than 15 degrees. As the limestone slab moved it broke into many smaller pieces. Today limestone pieces are scattered across an area of about 1.2 square kilometers. Some of these blocks are up to 385 meters across (Figure 9). Erenköy landslides can be easily recognized on GoogleEarth images. Pliocene limestone and partially mudstone detached near bedding planes and slipped down towards to Güzelyalı Village. The minimum vertical descent was about 100 meters. The Erenköy landslides were too large for geologists to easily notice. It has been noticed that there were large pieces of limestone blocks that were out of place in the area. Çanakkale and surrounding area would have been tectonically active since Late Miocene. Record (AFAD 2010) shows that 1875 Erenköy-Çanakkale Earthquake is responsible for Erenköy Landslide and the slide is responsible for scattering limestone blocks. Landslide material including limestone slabs easily transported on underlying mudstone layers. 
Probably the limestone blocks were most likely placed there as debris from multiple landslides caused by earthquake. This new research shows that all of these blocks in landslide debris replace from the more than one landslide.

Recent landslide near Güzelyalı Village is product of slow-moving creep type landslides which is the imperceptibly slow, steady, downward movement of slope forming soil (Yiğitbaş vd., 2005; Baba vd., 2005; Tatar vd., 2011). Numerous curved tree trunks are one of the indications of recent creep type of landslide. This study notices that sliding mass of recent landslide is the ancient landslide debris that is sliding over mudstone of Gazhanedere Formation. Considering recent landslide in same area it could be suggested that ancient landslide in same area is seasonal, where movement is within the depth of soil affected by seasonal changes in soil moisture and soil temperature. Most probably ancient landslide occurred during rainy season. It was assumed that landslide deposits near Güzelyall Village were produced by multiple landslide events. That happened within last a few hundred years and frequently repeated recent years. Complex internal structure is one of the indications that ancient landslide debris has slid several times since first movement (Figures 16a, b and 17a, $b, c)$. Soil consist of landslide debris is up to 10 meters thick in some places. Despite collected evidence of the slide is not immediately apparent at the site today. The slides originated possibly by earthquakes consisting of many events, probably several hundred years between them. The question of course is how many enormous landslides did occur and how many years between these landslides. That is the question could be studied and answered in the future. Slide shear surface located base of Alçitepe Formation or near top of Çamrakdere Formation or within mudstone interlayer's of these two unit. However, shear surface near Güzelyal area is located at the base of soil layer which is mostly represented by ancient landslide debris (Figures 16a, b and 17a, $b, c)$. Movement around this area has occurred on a shear surface that has an inclination of only a small number of degrees.

A research maybe conducted in the future on Güzelyal delta may explains emerging evidence that may show a dramatic increase in the amount of sediment transported from the landslide area and deposited in the Güzelyall delta after major landslide in 1875 and following years. Landslide material-debris located near Güzelyalı moved by gravity several times. The movements not occur in one episode, in events that were repeated over time.

Following the unusually heavy rains during the winter of 2013-2014, Erenköy and Güzelyall areas had been experiencing new landslide movement near the ancient landslide. Ancient landslide debris resting on Gazhanedere Formation offers danger signs for eastern Güzelyalı housing developments.

\section{DEĞINIILEN BELGELER}

AFAD, 2010. Aylık Deprem Raporu. 03/11/2010 Saros Körfezi Depremi (Ml=5.3), 26s. www.deprem. gov.tr/depremdokumanlari/198, https://deprem. afad.gov.tr/tarihseldepremler

AFAD, 2014. Gökçeada açıkları Ege Denizi Depremi Mw:6.5, 24/05/2014. Ön rapor $20 \mathrm{~s}$

Alkaç, O. ve Perinçek, D., 2009. Çanakkale'nin güneybatısının (Güzelyal1-İntepe) genel jeolojisi. ÇOMÜ Jeoloji Mühendisliği Bölümü Arşivi. Yayınlanmamıș Bitirme Tezi.

Ambraseys, N., 2002. The Seismic Activity of the Marmara Sea Region over the Last 2000 Years. Bull. Seism. Soc. Am. 92, no. 1, 1-18

Ambraseys, N., and Finkel, C., 1991. Long-term seismicity of Istanbul and of the Marmara Sea region, Terra 3, 527-539.

Arkeolojihaber, 2011. Çanakkale Boğazı'nda Kayıp Kent Bulundu. 26 Eylül 2011, 12664 
Atabey, A., Ayhan, I. ve Sakitaş, A., 2004. Çanakkale Havzasının Orta-Üst Miyosen Stratigrafisi, Maden Teknik Arama Dergisi, 128, 79-97.

Baba, A., Bozcu, M., Deniz, O., Kürçer, A., Kaya, M. A., Şengül, E., Ekinci, Y. ve Köse, K., 2005. Güzelyalı (Çanakkale) 27j paftası kuzeydoğu kesiminde heyelan etüt raporu. Proje Başkanı: Yiğitbaş, E., Proje Koordinatörü: Baba, A., Proje Danışmanı: Yılmazer, İ. Çanakkale Onsekiz Mart Üniversitesi Mühendislik-Mimarlık Fakültesi Jeoloji ve Jeofizik mühendisliği bölümleri. Yayınlanmamış rapor, $122 \mathrm{~s}$.

Bekler, T., Ekinci, Y.L., Demirci, A., Erginal, A.E., and Ertekin, C., 2011. Characterization of a Landslide Using Seismic Refraction, Electrical Resistivity and Hydrometer Methods, Adatepe Çanakkale, NW Turkey. Journal of Environmental and Engineering Geophysics, 16(3): 115-126.

Calvi, V.S., 1941. Erdbebenkatalog der Turkei und Einiger Benaehbarter Gebiete. Yayımlanmamış Rapor No.276, MTA Enstitüsü, 1941, Ankara.

Dirik,K., Belindir, F., Özsayın, E., Kutluay, A,. 2008. Yenice-Gönen Fay Zonu'nun neotektonik özellikleri ve paleosismolojisi. Proje no: TUJJBUDP04-02, final raporu, 91 sayfa

Duman, T., Çan, T., Emre, Ö., Kadiroğlu, F.T., Baştürk., N.B., Kılıç, T., Arslan, S., Özlap, S., Kartal R.F., Kalafat, D., Karakaya, F., Azak, T.E., Özel, N.M., Ergintav, S., Akar, S., Altınok, Y., Tekin, S., Cingöz, A., Kurt, A.İ., 2016. Seismotectonic database of Turkey. Bull Earthquake Eng. 1-40.

Ekinci, Y.L., Türkeş, M., Demirci, A., Erginal, A.E., 2013. Shallow and deep-seated regolith slides on deforested slopes in Çanakkale, NW Turkey. Geomorphology, 201: 70-79.

Emre, Ö., Duman, T.Y., Özalp, S., Şaroğlu, F., Olgun, Ş., Elmacı, H., Çan, T., 2016. Active fault database of Turkey. Bull Earthquake Eng. 54p.

Emre,Ö., Duman, T.Y., Özalp, S., Elmacı, H., Olgun, Ş ve Şaroğlu, F., 2013. Turkey Active Fault Map, Mineral Research and Exploration General Directorate Special Publication Series 30, AnkaraTurkey.

Erginal, AE., Öztürk, B., Ekinci, Y.L., Demirci, A. 2009. Investigation of the nature of slip surface using geochemical analyses and 2-D electrical resistivity tomography: a case study from Lapseki area, NW Turkey. Environmental Geology, 58(6): 1167-1175.

Gökaşan, E., Ergin, M., Özyalvaç, M., Sur, H.İ., Tur, H., Görüm, T., Ustaömer, T., Batuk, F.G., Alp, H., Birkan, H., Türker, A., Gezgin, E., Özturan, Ö., 2008, Factors controlling the morphological evolution of the Çanakkale Strait (Dardanelles, Turkey), Geo-Marine Letters, 28:107-129.

Gökaşan, E., Görüm, T., Tur, H., Batuk, F.G., 2012. Morpho-tectonic evolution of the Çanakkale Basin (NW Anatolia): evidence for a recent tectonic inversion from transpression to transtension. Geo Marine Letters, Vol. 32, Number 1, 227-239.

Gökaşan, E., Tur, H., Ergin, M., Görüm, T., Batuk, F.G., Sağc1, N., Ustaömer, T., Emem, O., Alp, H., 2010, Late Quaternary evolution of the Çanakkale Strait region (Dardanelles, NW Turkey): implications of a major erosional event for the postglacial Mediterranean-Marmara Sea connection, GeoMarine Letters, Vol. 30, Number 2, 113-131.

Gürbüz C., Aktar M., Eyidoğan H., Cisternas A., Haessler H., Barka A., Ergin M., Turkelli N., Polat O., Üçer B., Kuleli S., Barış $\square$ S., Kaypak B., Bekler T., Zor E., Biçmen F., Yoruk A., 2000. The seismotectonics of the Marmara Region (Turkey): Results from a microseismic experiment. Tectonophysics, 316, 1-17.

Highland, L.M., and Bobrowsky, Peter, 2008. The landslide handbook-A guide to understanding landslides: Reston, Virginia, U.S. Geological Survey Circular 1325, 129 p.

Kiratzi, A., 2018. The 12 June 2017 Mw 6.3 Lesvos Island (Aegean Sea) earthquake: Slip model and directivity estimated with finite-fault inversion. Tectonophysics 724-725, 1-10

Kiratzi, A.,and Svigkas, N., 2013. A study of the 8 January 2013 Mw5.8 earthquake sequence (Lemnos Island, East Aegean Sea). Tectonophysics 608, 452-460.

Kozanl1, Candan, 2008. Sözlü Görüşme. Çanakkale Arkeoloji Müzesi, Barbaros Mahallesi.100.Y1l Cad. Çanakkale.cankozanli@yahoo.com

Kürçer A, Deniz O, Baba A, Bozcu M., 2005. Güzelyalı (Çanakkale) Heyelanlarının Aktif Tektonizma İle İlişkisi, ATAG-9, 22-24 Eylül 2005, Sivas, Bildiriler Kitabı, 42-43. 
Kürçer, A., Chatzipetros, A., Tutkun, S. Z., Pavlides, S., Ateş, Ö., Valkaniotis, S,. 2008. The Yenice-Gönen active fault (NW Turkey): Active tectonics and palaeoseismology. Tectonophysics, 453, 263-275.

Kürçer, A., Özalp, S., Özdemir, E., Güldoğan Ç.U., Duman, T., 2016. Yüzey kırığı oluşturmuş faylar üzerinde aktif tektonik ve paleosismolojik araştırmalar hakkında örnek çalışma: Yenice Gönen Fayı, KB Türkiye. Doğal Kay. ve Eko. Bült. 21: 1-18

Okay, A., Siyako, M. ve Burkan, K.A., 1990. Biga Yarımadası'nın Jeolojisi ve Tektonik Evrimi, Türkiye Petrol Jeologları Derneği Bülteni, 2/1, 83-121.

Önem, Y., 1974. Gelibolu Yarımadası ve Çanakkale dolaylarının jeolojisi. TPAO Arama Grubu Arşivi, yayınlanmamış teknik rapor, 877, $30 \mathrm{~s}$.

Özalp, S., Kürçer, A., Özdemir, E., Duman, T. Y., 2016. The Bekten Fault: The palaeoseismic behavior and kinematic characteristics of an intervening segment of the North Anatolian fault zone, Southern Marmara Region, Turkey. Geodinamica Acta, 28, 347-362.

Özden, S., Bekler, T., Tutkun, S.Z., Kürçer, A., Ateş, Ö., Bekler, F.N. and Kalafat, D., 2009. Late Cenozoic stress field distribution in Biga Peninsula, NW Turkey. Geophysical. EGU General Assembly 2009, Research Abstracts, Vol. 11.

Özden, S., Över, S., Poyraz, S.A., Güneş, Y., Pınar, A., 2018. Tectonic implications of the 2017 Ayvacik (Çanakkale) earthquakes, Biga Peninsula, NW Turkey. Journal of Asian Earth Sciences 154, 125-141.

Perinçek, D. ve Karslıoğlu, Ö., 2007. Çanakkale Boğazı'nın oluşumu ve Kuvaterner yaşlı birimlerin dağılımında fayların rolü. 60. Türkiye Jeoloji kurultayı Bildiri Özetleri, 16-22 Nisan, Ankara, 478-479.

Perinçek, D., 1991, Possible strand of the North Anatolian Fault in the Thrace Basin, Turkey - An Interpretation. AAPG Bulletin 75, 241 - 257.

Perinçek, D., 2006. Marmara-Trakya havzalarının Yapısal Evrimi ve Fayların Zamansal Gelişimi. Çanakkale Onsekiz Mart Üniversitesi-GençJeo .(Jeoloji Öğrenci Topluluğu) Çanakkale, 27-38
Sarker, A.A. and Rashid, M.A.K.M., 2013. Landslide and Flashflood in Bangladesh. In: Shaw, R., Mallick, F., Islam, A. (Eds). Disaster Risk Reduction Approaches in Bangladesh. Springer Science and Business Media. Chapter 8, pp. 165191.

Siyako, M., 2006a. Trakya Havzası'nın Linyitli Kumtaşları, MTA Dergisi, 132, 63 - 73.

Siyako, M., 2006b. Trakya Bölgesi Litostratigrafi Birimleri (Tersiyer Bölümü). Stratigrafi Komitesi, Litostratigrafi Birimleri Serisi-2. MTA Genel Müdürlüğü yayını. $70 \mathrm{~s}$

Siyako, M.; Burkan, K.A. ve Okay, İ.A., 1989. Biga ve Gelibolu Yarımadalarının Tersiyer Jeolojisi ve Hidrokarbon olanakları. Türkiye Petrol Jeologları Derneği Bülteni, 1/3, 183-200.

Soysal, H., Sipahioğlu, S., Kolçak, D., Altınok, Y., 1981. Türkiye ve çevresinin tarihsel deprem kataloğu, TUBITAK proje no: TBAG341 Şehsuvarlığlu, H.Y., 1955.Asırlar Boyunca İstanbul, Cumhuriyet Yayınları, $253 \mathrm{~s}$

Sümengen, M.; Terlemez, İ.; Şentürk, K.; Karaköse, C.; Erkan, N.E.; Gürbüz, M. ve Atalay, Z., 1987. Gelibolu Yarımadası ve Güneybatı Trakya Tersiyer Havzasının Stratigrafisi, Sedimantolojisi ve Tektoniği, MTA Genel Müdürlüğü, Jeoloji Etütler Dairesi, yayımlanmamış teknik rapor, 8218, 337 sayfa.

Şentürk, M. ve Karaköse, C., 1987. Çanakkale Boğazı ve dolayının jeolojisi. Yayınlanmamış MTA Rap. No: 9333, Ankara.

Tan, O., Tapırdamaz, M.C., Yörük, 2008. The Earthquake Catalogues for Turkey. Turkish Journal of Earth Sciences, Vol. 17, pp. 405-418

Tatar, O., Perinçek, D., Köksal, O., Büyüksaraç, A., Berilgen, M., Bekler, T., Tunusluoğlu, C., Yalçıner, C. Ç., Ekinci, Y. L. ve Demirci, A., 2011. Jandarma Genel Komutanlığı Çanakkale Özel Eğitim Merkezi Komutanlığı tesislerinde 14 Temmuz 2011 tarihinde meydana gelen heyelanın jeolojik, jeofizik, jeoteknik ve yap1 etüd raporu. Çanakkale Onsekiz Mart Üniversitesi Mühendislik-Mimarlık Fakültesi Jeoloji, Jeofizik ve İnşaat mühendisliği bölümleri. Yıldız Teknik Üniversitesi Mühendislik Fakültesi İnşaat Mühendisliği Bölümü. Yayınlanmamış rapor, 257 sayfa. 
Temel, Ö.R. ve Çiftçi, N.B., 2002. Gelibolu Yarımadası, Gökçeada ve Bozcaada Tersiyer Çökellerinin Stratigrafisi ve Ortamsal Özellikleri. TPJD Bülteni, C:14, 2, 17-40

Tunusluoğlu, M.C., Karaca, Ö. ve Baba, A., 2009. Çanakkale Kenti güneybatısındaki (Güzelyal1) kütle hareketinin değerlendirilmesi. 62. Türkiye Jeoloji Kurultayı Bildiri Özetleri Kitapçı̆̆ı, s.406407, Ankara.

Türkeş, M., Erginal, A. E., Tatlı, H., Sarış, F. and Bayrakdar, C. 2006. Ambaroba Landslide: An anthropogenetically triggered rotational landslide in NW-Anatolia, Çanakkale, Turkey. In International Çanakkale Congress, 17-19 March 2006, Istanbul, Volume 2: 537-542.
Türkeş, M., Erginal, E., Demirci, A. ve Ekinci, Y. L. 2011. Çanakkale yöresi Ambaroba ve Mazilık heyelanlarının jeofiziksel, klimatolojik ve jeomorfolojik analizi. 5th Atmospheric Science Symposium Proceedings: 461-474. İstanbul Technical University, 27-29 (461-474) April, İstanbul - Turkey.

Yeşilyurt, S.K., Kabasakal, Ö.S.; Çolakoğlu, G. ve Güven, P., 2007. Çanakkale Boğazı Güneyinin Neojen Stratigrafisi ve Gastropoda-Pelecypoda Faunası (Çanakkale-KB Anadolu), Türkiye Jeoloji Kurultay1.

Yiğitbaş, E., Baba, A., Yılmazer, İ., Bozcu, M., Deniz, O., Kürçer, A., Kaya, M.A., Şengül, E., Ekinci, Y. ve Köse, K. 2005. Güzelyalı (Çanakkale) 27J Paftası Kuzeydoğu Kesiminde Heyelan Etüd Raporu, $122 \mathrm{~s}$. 